\title{
How to Achieve Effectiveness in Problem-Oriented Landscape Research: The Example of Research on Biotic Invasions
}

\author{
Christoph Kueffer \\ Department of Botany, University of Hawaii at Manoa, Honolulu, U.S.A. \& \\ transdisciplinarity-net, \\ Swiss Academies of Arts and Sciences, Berne, Switzerland \& \\ Institute of Integrative Biology, Department of Environmental Sciences, \\ Swiss Federal Institute of Technology, Zurich, Switzerland \\ email: christoph.kueffer@env.ethz.ch \\ http://www .env .ethz.ch/people/all/02720/kuefferc/ \\ Gertrude Hirsch Hadorn
Institute for Environmental Decisions, Department of Environmental Sciences, Swiss Federal Institute of Technology, Zurich, Switzerland \& transdisciplinarity-net,
Swiss Academies of Arts and Sciences, Berne, Switzerland email: gertrude.hirsch@env.ethz.ch
http://www.env.ethz.ch/environmental_philosophy/people/hirsch

\section{Living Reviews in Landscape Research ISSN 1863-7329}

Accepted on 1 July 2008

Published on 15 July 2008

\begin{abstract}
It is increasingly expected from environmental research such as landscape research that science directly contributes to the solving of pressing societal problems. However, despite increased efforts to direct research towards societal problems, it is not obvious if science has become more effective in supporting environmental problem-solving. We present in this article a framework that facilitates the analysis and design of problem-orientation in research fields. We then apply the proposed framework to a concrete example of a problem-oriented landscape research field - namely research on biotic invasions. Invasion research addresses the problem that some organisms, that have been introduced by humans to a new geographic area where they were previously not present, spread in the landscape and pose negative impacts.

We argue that problem-oriented research is more than applied research. Besides research on specific questions it also encompasses boundary management, i.e., deliberations among experts and stakeholders on the framing of adequate research questions about processes, values and practices for effective problem-solving. We postulate that such research may assist problem-solving in three ways, by analysing causal relationships (systems knowledge), clarifying conflicts of interests and values (target knowledge), or contributing to the development of appropriate means for action (transformation knowledge).

We show that over the past decades a broad range of different research approaches has emerged in the young field of invasion research in order to produce systems, target and transformation knowledge for invasive species management. Early research in the field was dominated by the development of systems knowledge, but increasingly the three knowledge forms are
\end{abstract}

This review is licensed under a Creative Commons Attribution-Non-Commercial-NoDerivs 2.0 Germany License. http://creativecommons.org/licenses/by-nc-nd/2.0/de/ 
treated more equally. The research field has also become more interdisciplinary and contextspecific.

Boundary management in invasion research is mainly restricted to informal networks (communities of practice), while formal processes such as transdisciplinary research are scarce. We suggest that the paucity of structured and explicit boundary management processes will limit the future development of a more effective science for invasive species management. In particular, we envisage three obstacles that can only be removed through explicit boundary management. First, the existing theoretical frameworks are currently only partly able to integrate natural and social sciences research on the processes underlying invasions. Second, a clarification of the normative thinking about alien plant invasions is needed. Third, research on transformation knowledge has so far not fundamentally challenged the existing conceptual framing and institutional setup of invasive species management.

Keywords: transdisciplinary research, boundary management, biotic invasions 


\section{Imprint / Terms of Use}

Living Reviews in Landscape Research is a peer reviewed open access journal published by the Leibniz Centre for Agricultural Landscape Research (ZALF), Eberswalder Straße 84, 15374 Müncheberg, Germany. ISSN 1863-7329.

This review is licensed under a Creative Commons Attribution-Non-Commercial-NoDerivs 2.0 Germany License: http://creativecommons.org/licenses/by-nc-nd/2.0/de/

Because a Living Reviews article can evolve over time, we recommend to cite the article as follows:

Christoph Kueffer and Gertrude Hirsch Hadorn,

"How to Achieve Effectiveness in Problem-Oriented Landscape Research: The Example of Research on Biotic Invasions",

Living Rev. Landscape Res., 2, (2008), 2. [Online Article]: cited [<date $>$ ], http://www.livingreviews.org/lrlr-2008-2

The date given as $<$ date $>$ then uniquely identifies the version of the article you are referring to.

\section{Article Revisions}

Living Reviews supports two different ways to keep its articles up-to-date:

Fast-track revision A fast-track revision provides the author with the opportunity to add short notices of current research results, trends and developments, or important publications to the article. A fast-track revision is refereed by the responsible subject editor. If an article has undergone a fast-track revision, a summary of changes will be listed here.

Major update A major update will include substantial changes and additions and is subject to full external refereeing. It is published with a new publication number.

For detailed documentation of an article's evolution, please refer always to the history document of the article's online version at http://www. livingreviews.org/lrlr-2008-2. 


\section{Contents}

1 Introduction

2 A theoretical framework for the analysis of the effectiveness of problem-oriented research

3 The societal problem of biotic invasions and the field of invasion research 14

3.1 The societal problem of biotic invasions . . . . . . . . . . . . . . . . 14

3.2 The field of invasion research . . . . . . . . . . . . . . . . . . . 14

4 The production of systems knowledge - Understanding the processes underlying biotic invasions

4.1 The classical model . . . . . . . . . . . . . . . . . . . . . . . 16

4.2 Phase transition models . . . . . . . . . . . . . . . . . . . . . . . . 17

4.3 Natural experiments . . . . . . . . . . . . . . . . . . . . . . . 17

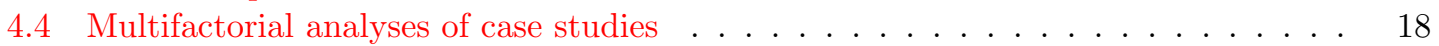

4.5 Landscape ecology . . . . . . . . . . . . . . . . . . . . . . . . . . . 18

4.6 Vector science . . . . . . . . . . . . . . . . . . . . . . . 18

4.7 Land use science . . . . . . . . . . . . . . . . . . . . . . . 18

5 The production of target knowledge - Valuation of the impacts of invasive species 21

5.1 Biological impact research . . . . . . . . . . . . . . . . . . . . . . . . . . 21

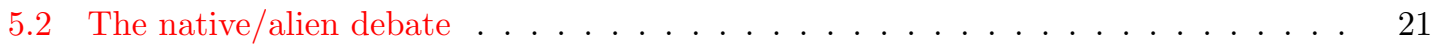

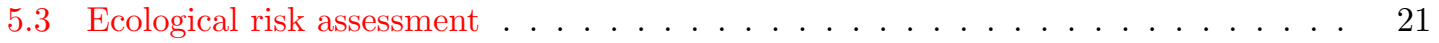

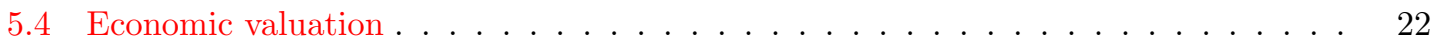

5.5 Socioeconomic valuation . . . . . . . . . . . . . . . . . . . . . 22

6 The production of transformation knowledge - Research that addresses the options for managing biotic invasions 24

6.1 Prevention . . . . . . . . . . . . . . . . . . . . . . 24

6.2 Early detection and eradication . . . . . . . . . . . . . . . . . . . . . . . . . . . . . . . .

6.3 The control of invasive species . . . . . . . . . . . . . . . . . 25

7 Discussion $\quad 28$

7.1 The evolution of invasion research: The search for an adequate framing of problemoriented research on biotic invasions . . . . . . . . . . . . . . . . . . . . . . . . . . . 28

7.2 Forms of boundary management . . . . . . . . . . . . . . . . . . . . 31

8 Conclusions $\quad 33$

9 Acknowledgements $\quad 34$

$\begin{array}{ll}\text { References } & 35\end{array}$

\section{List of Tables}

1 A categorisation of seven different research approaches that are used in invasion research to clarify systems knowledge. . . . . . . . . . . . . . . . . 
2 A categorisation of five different approaches that are used in invasion research to clarify target knowledge. . . . . . . . . . . . . . . . . . . .

3 A categorisation of three different management approaches, their links with systems and target knowledge, and their needs for transformation knowledge. . . . . . . . . 



\section{Introduction}

It is increasingly expected from landscape research and from environmental research in general that science directly contributes to the solving of pressing societal problems (e.g. Bocking, 2004). More and more problem-oriented research is funded that is explicitly designed to contribute to the solving of particular problems in society. However, despite increased efforts to direct environmental research towards problem-oriented research it is not obvious if science has become more effective in supporting environmental problem solving (Bocking, 2004; Cash et al., 2003). We present in this article a theoretical framework that facilitates the analysis of the problem-orientation of research fields, and helps to design more effective problem-oriented research. Our theoretical framework is based on scholarship that developed over the past few decades among theoreticians and practitioners of problem-oriented research (Bammer, 2005; Cash et al., 2003; Hirsch Hadorn, 2003; Klein et al., 2001; Nowotny et al., 2001; Pohl and Hirsch Hadorn, 2007). In the second part of the article we apply the proposed framework to a concrete example of a problem-oriented landscape research field - namely research on biotic invasions. Some organisms that have been introduced through human transportation to new geographic areas, where they were previously not present, have spread in the landscape and can have negative impacts. Such biotic invasions can lead to massive economic and ecologic costs (Mack et al., 2000; Millennium Ecosystem Assessment, 2005; Pimentel et al., 2005), and the management of invasive species is therefore a high priority in national and international environmental policies (McNeely et al., 2001; Mooney et al., 2005). Our review is intended to comprehensively discuss invasion research since the late 1950s, but is necessarily incomplete and simplifies the structure and diversity of the research field for the purpose of our analysis. We think that invasion research is typical for landscape research in several ways, and that therefore our analysis will also help to design more effective science in other fields of problemoriented landscape research. Particularly, biotic invasions are processes that take place on multiple spatial scales with a particular relevance of the landscape scale. Further, biotic invasions represent a complex societal issue because scientific knowledge is highly uncertain, and both conflicts of interests and values are prominent in the problem-solving context (post-normal situation sensu Funtowicz and Ravetz (1993)), and such post-normal situations are common in environmental research. In the case of invasion research, for instance, many different actors (and their particular interests) from a wide range of professional fields are involved in problem-solving (Mooney et al., 2005; Wittenberg and Cock, 2001), and debates about the value judgments implicated in the issue are vivid (e.g. Simberloff, 2003; Theodoropoulos, 2003). 


\section{A theoretical framework for the analysis of the effective- ness of problem-oriented research}

Expertise on effective problem-oriented research has developed over the past decades under a broad number of keywords, including transdisciplinary research (e.g. Hirsch Hadorn, 2003; Pohl and Hirsch Hadorn, 2007), integration and implementation sciences (Bammer, 2005), Mode 2 knowledge production (Nowotny et al., 2001), post-normal science (Funtowicz and Ravetz, 1993), socio-ecological research (Becker, 2002; Becker and Jahn, 2006), and effective knowledge systems (Cash et al., 2003). While some of these scholars have attempted to developed novel scientific concepts for particular thematic research fields, e.g. sustainable development (Brand, 2000), others have worked on a general methodology for effective problem-oriented research (cf. Kueffer et al., 2007a) or have proposed quality criteria for evaluating transdisciplinary research projects (Bergmann et al., 2005). It has been suggested that there is a high potential to generalise such methodological insights across research fields (Bammer, 2005). But so far most theoretical thinking has focused on adapting research on the level of individual research projects or programmes (Hirsch Hadorn et al., 2008), while the methodological implications of attempting effective science on the level of a whole research field have rarely been considered. We propose in the following a framework, derived from design principles for transdisciplinary research projects compiled by Pohl and Hirsch Hadorn (2007), that facilitates the analysis of the problem-orientation of research fields, and helps to design effective problem-oriented research.

A major challenge of much environmental problem solving is that often facts are highly uncertain, and conflicts of interests and values are prominent in the problem-solving context (post-normal situations sensu Funtowicz and Ravetz (1993)). In such post-normal situations facts and values are closely entangled - for instance scientific advice may be deliberately produced to support the views of particular stakeholders (Pielke Jr, 2002), and the effectiveness of science depends on the capacity of the existing institutions to implement the proposed measures (Pohl and Hirsch Hadorn, 2007). Therefore the effectiveness of problem solving strategies depends simultaneously on three factors: a scientifically adequate understanding of the causal relations relevant to the problem (credibility), an adequate treatment of stakeholders' interests and values during the research and problem-solving process (legitimacy), and an adequate design of problem-solving practices that take into consideration the constraints and options of the implementing actors (relevance) (Bocking, 2004; Cash et al., 2003; Pohl and Hirsch Hadorn, 2007). Consequently, problem-solving is confronted with three types of questions (Figure 1): what is an adequate causal understanding of the problem? What are the relevant conflicts of interest and values and how should they be considered in the problem-solving process? What are adequate means to solve the problem given the constraints and options of the relevant actors?

Importantly, these three challenges are interrelated and value-laden (Cash et al., 2003; Funtowicz and Ravetz, 1993; Pohl and Hirsch Hadorn, 2007). A certain causal understanding of a problem may favour some problem solving means over others, and this may in turn serve some stakeholders better than others. For instance, the development of responses to climate change may be based on a problem understanding that focuses on the reduction of anthropogenic $\mathrm{CO}_{2}$ output, the control of the air $\mathrm{CO}_{2}$ level, or mitigations of the consequences of a changing climate. The corresponding problem-solving practices may, respectively, be an investment in public transport systems, the planting of forests as $\mathrm{CO}_{2}$ sinks, or the construction of sea walls at sea shores. Different stakeholders will favour different solutions and therefore different problem framings.

Given the three challenges introduced above, it can be expected that science may assist problemsolving in three ways by, respectively, analysing casual relationships, clarifying conflicts of interests and values, or contributing to the development of appropriate means for action. These three basic types of scientific contributions have been termed systems, target and transformation knowledge (Figure 1) (Pohl and Hirsch Hadorn, 2007; ProClim, 1997). Systems knowledge assists in reducing

Living Reviews in Landscape Research

http://www. livingreviews.org/lrlr-2008-2 


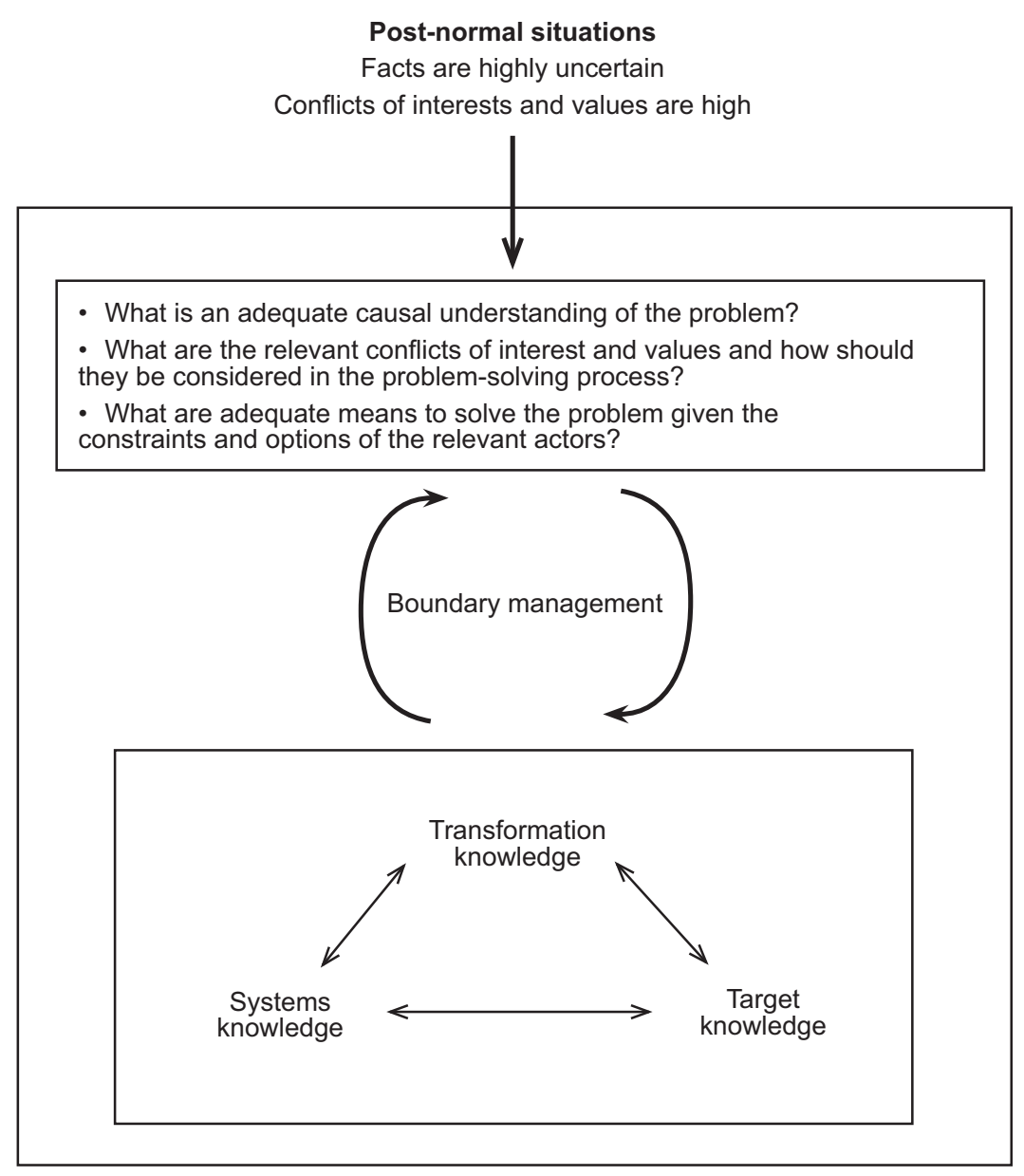

Figure 1: A conceptualisation of effective problem-oriented research. In situations where facts are highly uncertain and conflicts of interests and values are high (post-normal situations), the effectiveness of sciencebased societal problem-solving depends simultaneously on the adequateness of i. the causal understanding of the problem, ii. the handling of conflicts of interests and values, and iii. the means of action. Science can contribute to the clarification of these points through the production of systems, target and transformation knowledge, respectively. However, the link between the scientific production of these interdependent knowledge forms and an adequate understanding and handling of the problem is not evident and has to be clarified through deliberation among experts and stakeholders (boundary management). Such boundary management is itself a part of effective problem-oriented research. 
the uncertainties regarding the understanding of the causal relationships relevant for the genesis and possible further development of a problem (Figure 2). Systems knowledge confronts the difficulty of dealing with the complexity of concrete real-world cases, such as complex societynature-interactions (e.g. Becker and Jahn, 2006), based on abstract insights from a laboratory, a model or a theory. Target knowledge assists in clarifying conflicts of interests and values entangled within the problem solving process (Figure 3). The determination of the relevant stakeholders, conflicts of interests and values is related to issues of empowerment and inclusion/exclusion of stakeholders and experts, and therefore needs transparency and reflexivity (Elzinga, 2008). Transformation knowledge assists in developing problem solving means that take existing practices and institutions into consideration and help adapt them to the problem (Figure 4). Systems, target and transformation knowledge are interrelated.

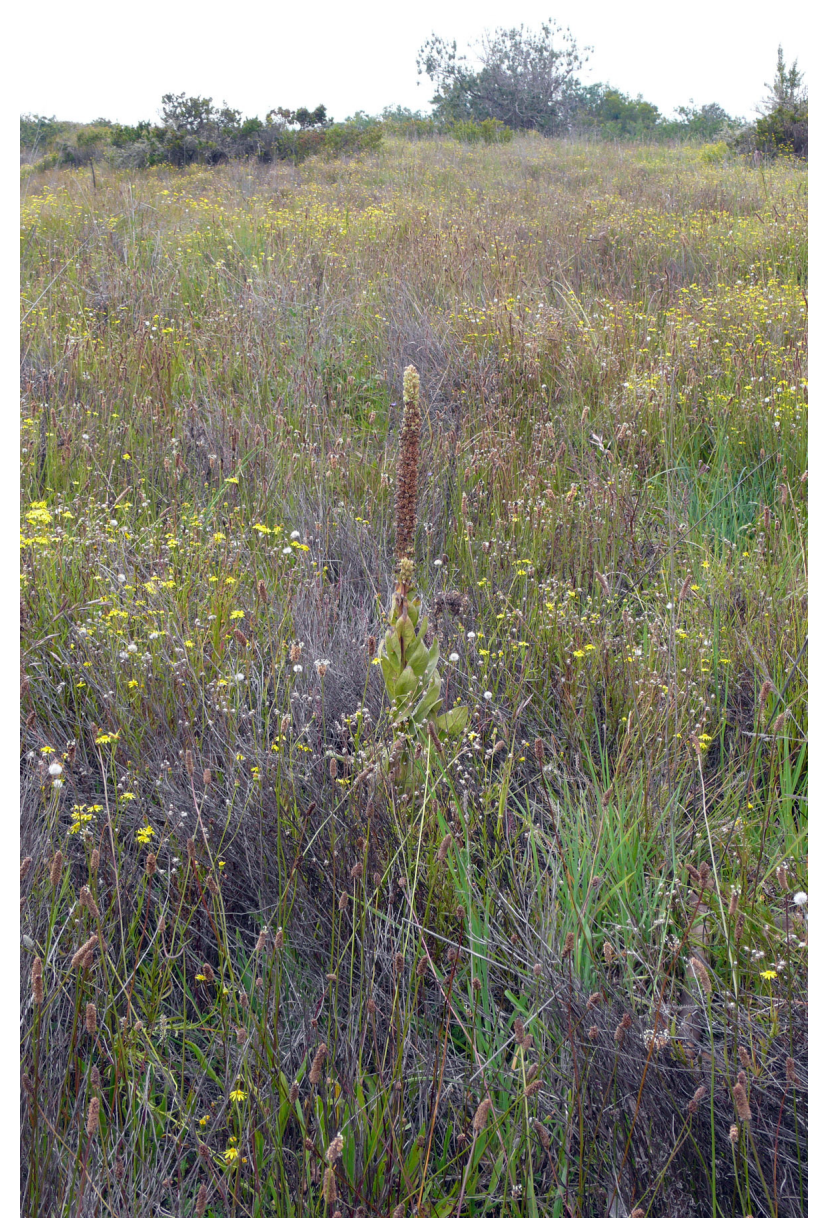

Figure 2: Research on the processes underlying biotic invasions (systems knowledge) increasingly considers human agency as an important explanatory factor. The picture shows a subalpine grassland at the slope of Mauna Kea in Hawaii covered in alien grasses and herbs. The past land use of this area as a cattle ranch, that involved the deliberate sowing of grazing-adapted alien species and the accidental introduction of further alien species as contaminants of the seed, helps to explain the invasion of alien species such as Holcus lanatus, Plantago lanceolata, Senecio madagascariensis or Verbascum thapsus in these areas (Photo by Eva Schumacher).

Living Reviews in Landscape Research

http://www.livingreviews.org/lrlr-2008-2 

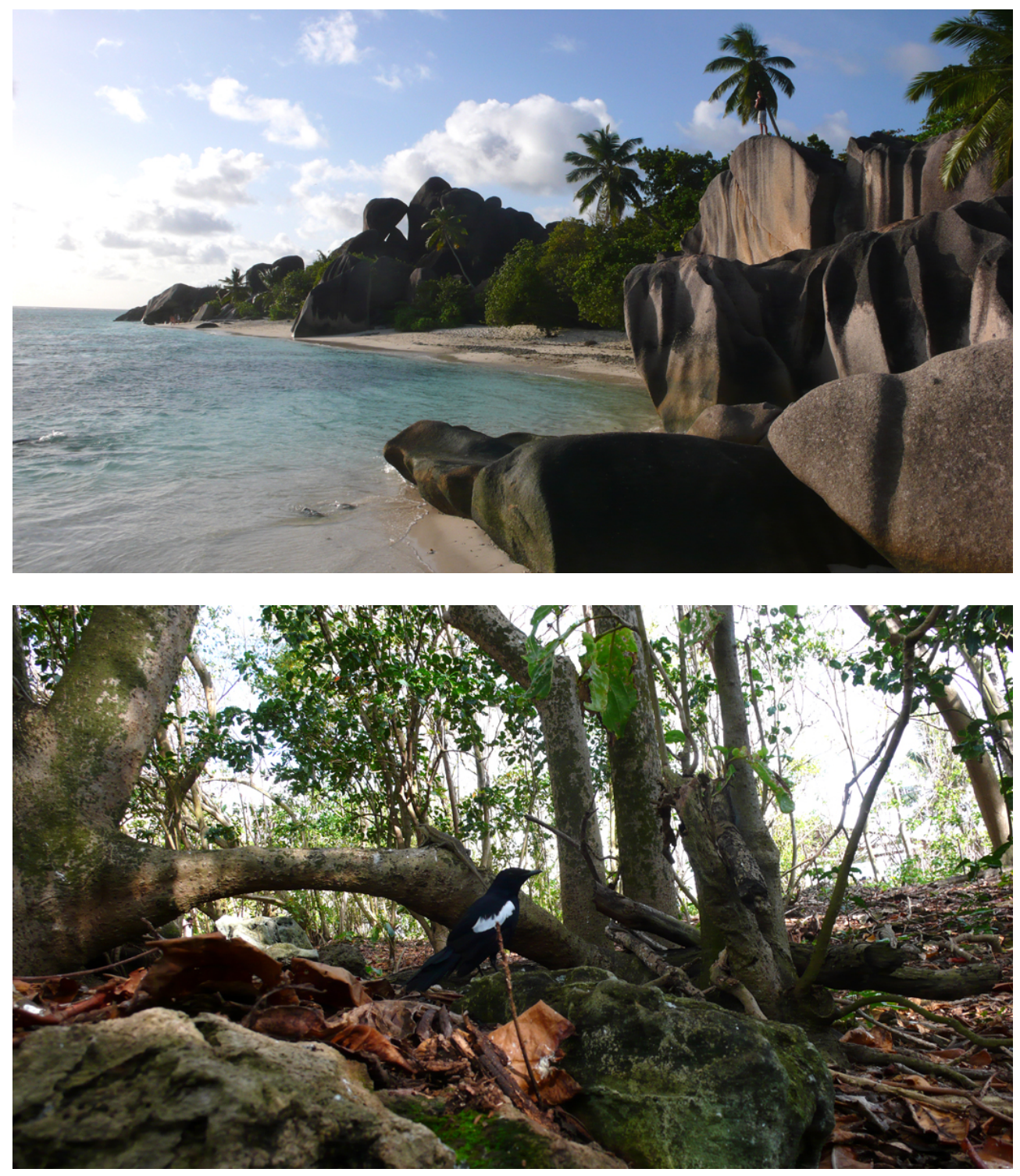

Figure 3: Research on target knowledge helps to clarify the valuation of the impacts of invasive species and their management. On tropical oceanic islands, Coconut palms (Cocos nucifera) are an important element of the landscape aesthetics of beaches for tourists (picture above) and a valuable source of food and building material for local people. However, in Seychelles, Coconut palms are considered to be invasive by nature conservationists. Native lowland vegetation, which is a critical habitat for endangered endemic birds, only recovers after the removal of these palms (picture below, Seychelles Magpie Robin Copsychus sechellarum on Aride Island). The valuation of the Coconut palm is further complicated because on many oceanic islands it is not known if the species is native or alien (Photos by Eva Schumacher). 


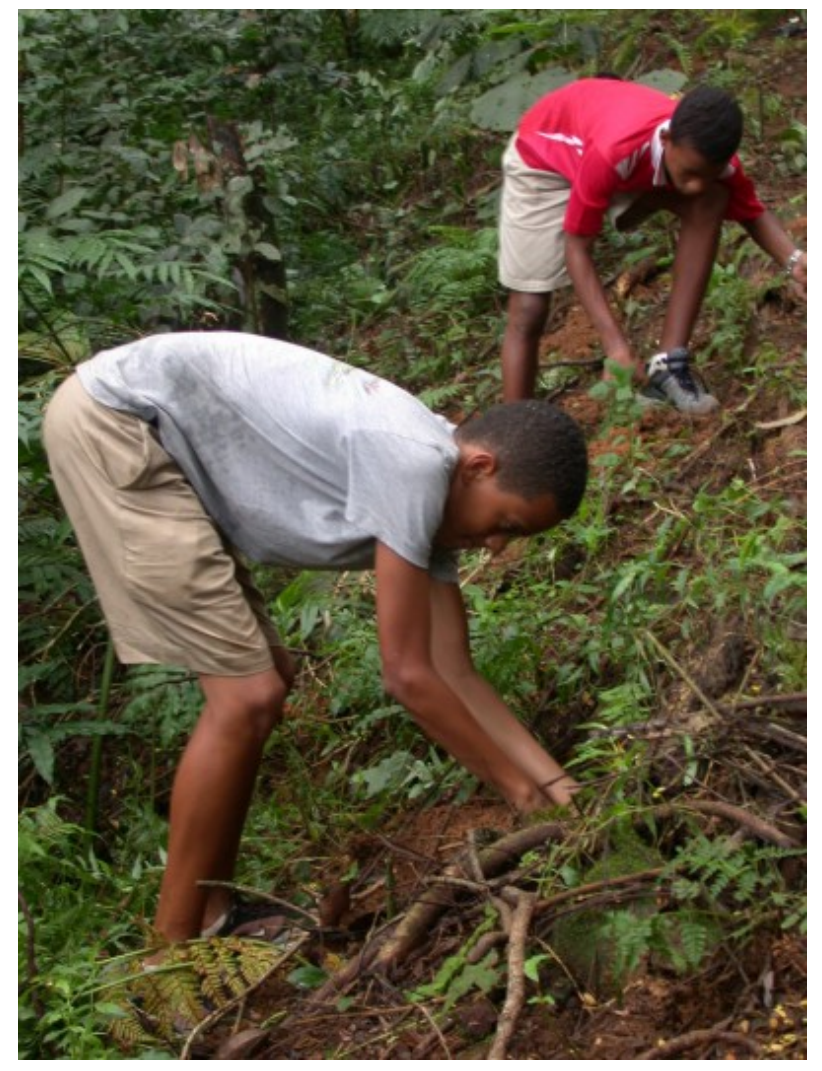

Figure 4: Research on transformation knowledge enhances the options of actors to take action. The control of an invasive species, for instance, is only effective if the removal is considered in an ecosystem context and a broad alliance of stakeholders support the actions. In Seychelles, control programmes by the Ministry of Environment are accompanied by replanting the targeted areas with native species, whereby the local community is involved. The picture shows school children planting endemic palms after the eradication of the invasive shrub Clidemia hirta (Photo by Stefan Zemp). 
It is important to note that there is no evident link between the three challenges in societal problem-solving and the three knowledge forms - rather this link has to be clarified recurrently through joint problem structuring among different experts and stakeholders. Such deliberations at the boundary between science and management, that are typical for post-normal situations, may be called "boundary management" (Figure 1) (Cash et al., 2003; Hellström and Jacob, 2003). There are structured research processes such as transdisciplinary research (Pohl and Hirsch Hadorn, 2007) and institutional forms such as boundary organisations (Hellström and Jacob, 2003) that facilitate boundary management, but often boundary management is not conducted in an explicit and structured way. Boundary management ensures that the relevant academic and non-academic expert and stakeholder perspectives are adequately represented in the research and problem-solving process (Hellström and Jacob, 2003; Pohl and Hirsch Hadorn, 2007), and that the framing of research questions is adequate for supporting the decisions of actors (Hirsch, 1993, 1995). The process is called boundary management because the boundaries between different forms of academic and nonacademic expertise and between facts and opinions (interests and values) are reconfigured. Because boundary management is itself based on (tentative) scientific expertise, boundary management and research on specific questions have to alternate in recursive cycles (Pohl and Hirsch Hadorn, 2007), and effective problem-oriented research encompasses both research on specific questions and boundary management.

In summary, in this paragraph we attempted to decompose the complexity of science-based problem solving in post-normal situations into a number of different processes (Figure 1). In particular, we argue that it is helpful to consider three types of scientific advice - systems, target and transformation knowledge - but that adequate research questions on the three types of knowledge can only be identified through explicit deliberation among experts and stakeholders (boundary management). Although this is necessarily a simplification, we think that it is helpful to analyse the problem-orientation of whole research fields. In the following we describe research on biotic invasions according to the following questions: what systems, target and transformation knowledge is produced? How is this systems, target and transformation knowledge interrelated? What mechanisms are in place to ensure boundary management? 


\section{The societal problem of biotic invasions and the field of invasion research}

\subsection{The societal problem of biotic invasions}

There is no consensus among experts on the definition of the terms "biotic invasion" and "invasive species". In all definitions the terms include the spread of organisms in the landscape, with "invasive species" relating to the organisms involved and "biotic invasion" referring to the overall process. However, while some experts refer only to those organisms that spread in an area where they would not have been present without human assistance (so-called alien or non-native species), others refer to any spreading organisms, including those that had been present in the general geographic area (e.g. a continent, country or island) without human assistance (native species). Further, some experts reserve the term "invasive" only for those species that are perceived to have negative economic or ecological impacts. Given these two dimensions, spreading species that are either only alien, or native and alien species, and that either pose a perceived problem or not, may be called invasive (for an extensive discussion of the terminology see Colautti and McIsaac, 2004; Daehler, 2001; Davis and Thompson, 2000; Richardson et al., 2000).

The different meanings of the terms reflect the dynamics of the research field that are discussed in this article. We therefore do not use only one definition of "invasive species" or "biotic invasion" in this article, but rather review any literature that attempts to be of relevance to the understanding and management of biotic invasions according to its own implicit definition of biotic invasion.

At present the societal problem of biotic invasions is typically framed as follows: the problem of biotic invasions has emerged because of the massive increase in global human travel and transportation over the past few centuries, which led to the introduction of large numbers of diseases, animal and plant species to new areas where they would not have been present without human assistance. It has for instance been estimated that more than 50,000 alien species have been introduced to the U.S.A. (cf. Pimentel et al., 2005). A small proportion of alien species have the potential to spread in a landscape and to achieve large population sizes. These species are called invasive alien species and some of them are thought to lead to massive economic and ecologic costs in the areas where they were introduced (Mack et al., 2000; Millennium Ecosystem Assessment, 2005; Pimentel et al., 2005). The costs of biotic invasions in the United States alone have been estimated to amount to almost US\$120 billion per year (Pimentel et al., 2005), and invasive alien species were identified as one of the five major causes of species extinctions, alongside habitat destruction, over-exploitation, climate change, and pollution (Millennium Ecosystem Assessment, 2005). Biotic invasions are therefore nowadays considered a major driver of global environmental change (Vitousek et al., 1997) and a high priority in national and international environmental policies, including Article $8 \mathrm{~h}$ of the Convention on Biological Diversity of the Rio Declaration (McNeely, 2001; Mooney et al., 2005). It is expected that the scale of the problem will increase in the future (Lodge et al., 2006; Millennium Ecosystem Assessment, 2005).

\subsection{The field of invasion research}

An explicit research field focused on biotic invasions emerged in the late 1950s from ecology (Davis, 2006; Richardson and Pyšek, 2008). The book entitled "The Ecology of Invasions by Animals and Plants" by Charles Elton published in 1958 is generally seen as the starting point of systematic research on biotic invasions, and the research field that emerged in response to Elton's book is generally called invasion biology. However, it is important to note that the spread of nonnative species had been addressed by naturalists since the early 19th century (Cadotte, 2006; Kowarik, 2003; Trepl, 1990). In fact, several research questions that are discussed in this review as innovations of invasion biology had been addressed before 1958 and were thereafter neglected

Living Reviews in Landscape Research

http://www. livingreviews.org/lrlr-2008-2 
for some time. This is particularly the case for European plant ecology that had discussed human agency as a relevant causal factor of biotic invasions since the 19th century (Kowarik, 2003; Trepl, 1990). However, because in this article we are interested in the formation of problem-oriented research as a clearly defined research field, we focus our review on the period since the publication of Elton's book and mention earlier research only in some cases. Since the late 1990s (Mooney et al., 2005), mainstream research on biotic invasion widened its focus and now includes a broad range of natural and social scientists. Because we are interested in the transformation of research focused on biotic invasions from an ecological sub-discipline to a multidisciplinary research field we propose and use in this article the broader term 'invasion research' for systematic research on biotic invasions. 


\section{The production of systems knowledge - Understanding the processes underlying biotic invasions}

Seven different research approaches can be distinguished that have been or are used in invasion research to clarify systems knowledge. These research approaches differ in their research questions and methods, and have different implications for problem solving (Table 1). They are introduced shortly in the following in their historical order.

\subsection{The classical model}

The classical model of biotic invasions structured research on the causal relationships of biotic invasions along two main questions (Drake et al., 1989; Williamson, 1996): what factors determine whether a species is an invader or not (species invasiveness)?, and 2) what characteristics explain why some habitats are more vulnerable to invasions than others (habitat invasibility)? The two questions restricted the field of invasion research to population and community ecologists. In particular, explicit spatial processes were treated only marginally by using highly generalised mathematical models for describing the spread of invasive species in space (Shigesada and Kawasaki, 1997; Williamson, 1996), and these spread models were not linked to research on species invasiveness or habitat invasibility. This neglect was problematic because it was shown that the number of individuals (e.g. larvae, seeds or other forms of propagules such as vegetative parts of plants) that arrive at a site (propagule pressure) is an important factor for explaining the degree of invasion (Lonsdale, 1999; Williamson, 1996). For the prediction of propagule pressure at a given site, processes at larger spatial scales such as population spread, seed dispersal or human transportation need to be considered (Lockwood et al., 2005; With, 2002). In the classical model these processes were not explicitly studied, yet propagule pressure was included in analyses as a third but unstudied explanatory factor external to the studied system.

Research on plant invasiveness (Daehler, 1998, 2003; Grotkopp et al., 2002; Kolar and Lodge, 2001; Rejmanek, 1996; Richardson and Pyšek, 2006; Sakai et al., 2001) and habitat invasibility (Alpert et al., 2000; Davis et al., 2000; Drake et al., 1989; Lonsdale, 1999; Stohlgren et al., 1999) was mostly based on global biogeographic comparisons of descriptive natural history information or experimental studies of single species, and relied on the assumption that the alien provenance of a species is an important explanatory factor. However, to date it is not clear if invasive alien species generally differ from native species with a high potential to colonise new areas (Thompson et al., 1995). The most consistent predictors for the invasiveness of a species are the history of being invasive in other regions and a matching between the climates of the native and introduce areas (Kolar and Lodge, 2001). The few more specific traits that proved to be more generally associated with invasive species (Kolar and Lodge, 2001; Richardson and Pyšek, 2006) are mostly those already identified for weeds, whether native or alien (Baker, 1974). For instance, invasive species tend to exhibit high growth rates and seed outputs and have efficient dispersal mechanisms such as by wind or birds (Kolar and Lodge, 2001), but these differences depend on the environmental conditions, and invasive species do not generally outperform native species (Daehler, 2003).

Research on habitat invasibility led to generalisations such as that (anthropogenically) disturbed, and resource-rich, early-successional habitats are more vulnerable to invasions than undisturbed, resource-poor and late-successional habitats (Alpert et al., 2000; Davis et al., 2000; Drake et al., 1989). It also became evident that the presence of invasive species can have a strong influence on the functioning of the invaded ecosystem (Levine et al., 2003; Vitousek, 1990), and in particular that in some cases invasive species change habitat conditions in a way that facilitate further invasions (Simberloff, 2006).

Research on species invasiveness and habitat invasibility have so far not been successful in providing robust prediction beyond the heuristics mentioned above (Mack and Barrett, 2002).

Living Reviews in Landscape Research

http://www. livingreviews.org/lrlr-2008-2 
However, a large, global dataset on biotic invasions has accumulated, which is rather unique for ecology and provides opportunities for studying invasion patterns as well as general ecological patterns through data mining (Cadotte et al., 2006b; Crall et al., 2006).

\subsection{Phase transition models}

Phase transition models are based on the assumption that invasion processes can be divided into different phases that are characterised by different ecological and evolutionary processes. Originally, three different phases were recognised: i. transport to a new area, ii. establishment and possibly lag-phase during which the population size remains small, and iii. spread (Kolar and Lodge, 2001; Richardson et al., 2000; Williamson, 1996). Recently, the particularities of the establishment phase in contrast to the spread phase have been studied in more detail (Kolar and Lodge, 2002; Marchetti et al., 2004; Mack and Barrett, 2002; Puth and Post, 2005). Dietz and Edwards (2006) proposed to further divide the spread phase into a primary and secondary invasion phase. They argue that initial spread happens in highly disturbed habitats by species that had no time to adapt to local environmental conditions, and that invasive alien species invade less disturbed habitats only after adaptation to local conditions during primary invasion. Facon et al. (2006) more generally emphasised the need to consider evolutionary and habitat changes with the progression of an invasion.

\subsection{Natural experiments}

Research according to the classical model produced results that touched upon key questions in general ecology, and this triggered an interest among ecologists to use biotic invasions for the study of basic ecological principles (Cadotte et al., 2006a; Callaway and Maron, 2006; Sax et al., 2007). In this way biotic invasions can be understood as large-scale, so called "natural experiments" (Diamond, 1983) that are unique research opportunities for basic ecology (Cadotte et al., 2006a). The research on habitat invasibility resonated with major research interests in community and ecosystem ecology that address the relationship between biodiversity and ecosystem functioning, or the relative importance of random and deterministic processes in community assembly (Cadotte et al., 2006a; Callaway and Maron, 2006; Sax et al., 2007). For example, one of the discussed aspects, already addressed by Elton (1958), was the hypothesis that species-richer habitats are more resistant to biotic invasions than species-poor habitats (Fridley et al., 2007; Levine et al., 2004). The relevance of propagule pressure for community assembly was further studied with a more theoretical focus (Callaway and Maron, 2006). Contrary to expectation, it emerged that natural ecosystems are often not saturated with species (Sax et al., 2007). In some cases, the alien provenance of the invasive species was the critical factor explaining invasion success. Alien species can profit in the introduced area from the release from their natural enemies such as pathogens or herbivores that are only present in the area of origin (Keane and Crawley, 2002). Additionally, some plant species compete with neighbouring plants by releasing chemicals (allelopathy). While in the native range the neighbouring plants are adapted through long-term coevolution to cope with these chemicals, this is not the case for plants in the area of introduction that consequently suffer heavily from allelopathic substances of invasive alien species (Callaway and Maron, 2006). These observations have provided general insights into the regulation of plant populations and the structuring of ecological communities. Another recent observation that owes much to invasion research has been that some species have the ability to evolve rapidly in ecologically relevant time spans (Callaway and Maron, 2006; Facon et al., 2006; Richardson and Pyšek, 2006). Species niches, i.e., the specialisation of a species in environmental space, may therefore be less stable than previously thought (Broennimann et al., 2007; Holt et al., 2005). 


\subsection{Multifactorial analyses of case studies}

It has been recurrently concluded that invasion processes are often idiosyncratic and that a multifactorial understanding of particular cases (Kueffer, 2006; Orians et al., 1986; Shrader-Frechette, 2001) is therefore needed (Callaway and Maron, 2006; Eppstein and Molofsky, 2007; Williamson, 1996). For instance, the impact of herbivores on invasive species depends on soil fertility (Blumenthal, 2005), and this relation is further linked to propagule pressure (Sanders et al., 2007). Invasions interact in complex ways with anthropogenic habitat modification (Didham et al., 2007), climate change (Thuiller et al., 2007) and other global change factors (Mooney and Hobbs, 2000).

\subsection{Landscape ecology}

Throughout most of the history of invasion biology, the spatial spread of invasive species was described by fitting highly generalised mathematical models (Shigesada and Kawasaki, 1997; Williamson, 1996; With, 2002). With (2002) initiated a broader research interest in landscape ecological research that explicitly addresses the influence of landscape structure on invasions, and it became evident that the spatial and temporal variation of environmental factors influences the spread of invasive species (Hastings et al., 2005; Melbourne et al., 2007). Landscape research on biotic invasions awaits a synthesis, but it appears that the integration of different spatial scales will be a major challenge in invasion research in the coming years (Kühn and Klotz, 2007; Pauchard and McKinney, 2006; Pyšek and Hulme, 2005). While the application of spatial ecology to biotic invasions has attracted interest, other fields of landscape research have so far mostly ignored the issue, even though geographers have recurrently emphasised the value of their expertise for studies of biotic invasions (e.g. Vale and Parker, 1980). Contributions from physical geography may for instance come from remote sensing (Asner and Vitousek, 2005; Bradley and Mustard, 2006) and GIS modelling (Peterson, 2003).

\subsection{Vector science}

The study of transportation vectors or pathways has become an active research area over the past few years (Kowarik and von der Lippe, 2007; Lodge et al., 2006; Meyerson and Mooney, 2007; Mooney et al., 2005; Mack and Barrett, 2002; Ruiz and Carlton, 2003). Because of the relevance of human agency for transportation, such research necessarily has to integrate natural and social sciences. Important past and present transportation factors that contribute to explaining distributions of alien species include colonial expansion, wars, ballast water of ships, plant and animal trade, railway, road and water canal networks, agricultural and forestry activities, botanical gardens and urbanisation (McNeely, 2001; Ruiz and Carlton, 2003). A well-studied example is the role of ornamental trade in biotic invasions (Dehnen-Schmutz et al., 2007a,b; Reichard and White, 2001). A relevant aspect of deliberate human-assisted introductions is that these are nonrandom; i.e., deliberately introduced organisms are often selected or bred specifically for the local conditions (e.g. in forestry Richardson, 1998). In order to reconstruct paths and predict future transport pathways, a thorough understanding of peoples' motivations for moving particular plants is needed (Brook, 2003; Daehler, 2007; Mack, 2001; McNeely, 2001).

\subsection{Land use science}

A multitude of studies have shown the relevance of anthropogenic habitat modification and land use for explaining biotic invasions (e.g. Deutschewitz et al., 2003; Hobbs, 2000; Maskell et al., 2006; Pauchard and Alaback, 2004). For the understanding of land use practices that influence plant invasions, social sciences research on human activities is essential. Not only current, but also

Living Reviews in Landscape Research

http://www. livingreviews.org/lrlr-2008-2 
the legacy of past land use can be relevant for current invasion processes (Domènech et al., 2005; Von Holle and Motzkin, 2007).

The urban ecosystem is a pronounced case of an ecosystem shaped by human activity that is of relevance to invasion research. Urban areas function as hubs for biotic exchange (La Sorte et al., 2007, and citations therein) and create novel habitats favourable for alien species. The influence of human factors on the occurrence of invasive species in urban areas is, for instance, evident in the cases of the vegetation composition of green spaces (e.g. Thompson et al., 2003), or the presence of invasive fire ants (Plowes et al., 2007).

Another human-dominated system with high relevance to invasions is agricultural land (Smith et al., 2006). In Europe, alien species that were introduced with early agriculture are more often associated with crops from this time period (cereals), while recently introduced weeds are more often associated with recently introduced crops (maize, rape) (Pyšek et al., 2005). Agricultural practices may influence the evolution of invasive species (Franks et al., 2004; Kowarik, 2003). In turn, invasions can feed back on land use decisions of farmers (Schneider and Geoghegan, 2006). Through the expansion of agri-environmental schemes and extensification of agriculture in Europe and North America, socio-political changes may influence invasion spread (Donald and Evans, 2006).

Research on the relation between land use and biotic invasions has so far mainly compiled case examples, and waits for a conceptual synthesis (cf. Kueffer and Daehler, 2008). It is directly related to the management of invasive species in human-dominated habitats. Such an integration of invasive species management in different economic sectors has been termed "mainstreaming of invasive species management" (Petersen and Huntley, 2005). 
Table 1: A categorisation of seven different research approaches that are used in invasion research to clarify systems knowledge (see text for further explanation).

\begin{tabular}{|c|c|c|c|}
\hline & Research approach & Important insights & Link with application \\
\hline Classical model & $\begin{array}{l}\text { Biogeographic comparisons } \\
\text { of invasiveness and invasi- } \\
\text { bility. The alien provenance } \\
\text { of a species is the critical } \\
\text { explanatory factor. }\end{array}$ & $\begin{array}{l}\text { Prediction of invasiveness } \\
\text { and invasibility. A few in- } \\
\text { sights into general ecological } \\
\text { principles, esp. regarding } \\
\text { the relevance of functional } \\
\text { groups of species and propag- } \\
\text { ule pressure. }\end{array}$ & $\begin{array}{l}\text { Awareness building, devel- } \\
\text { opment of risk assessment } \\
\text { systems, and general habi- } \\
\text { tat management guide- } \\
\text { lines. }\end{array}$ \\
\hline
\end{tabular}

Phase transition mod- Alien species invasions are els

$\begin{array}{ll}\text { Natural experiments } & \text { Alien invasions are used } \\ & \text { as natural experiments to } \\ \text { clarify basic ecological prin- } \\ \text { ciples. }\end{array}$

Multifactorial case studies

$\begin{array}{ll}\text { Landscape ecology } & \begin{array}{l}\text { Invasions are explicitly con- } \\ \text { sidered as spatio-temporal } \\ \text { ecological processes. }\end{array}\end{array}$

Vector science

Land use science considered unique ecological processes, and it is assumed that several distinct phase of an invasion need to be studied. ciples.

Invasions interact in complex ways with the invasion context, and other global change drivers. Need for multifactorial analyses of particular invasion cases.

Transportation of alien species on different scales is crucial for the understanding of invasions and is shaped by human action. Need for integrative research.

Land use patterns are important to explain invasibility, and are shaped by human action. Need for integrative social and natural sciences research. social and natural sciences
New insights into community assembly (e.g. natural ecosystems are often not saturated with species; relevance of dispersal limitation; scaledependence of relationship between biodiversity and invasibility; coevolution of biotic communities) and rapid evolution.

Synergistic interactions with habitat modification and other global change factors are highly relevant but poorly understood. Increased emphasis on the idiosyncratic nature and context dependence of invasions.

Spatio-temporal dynamics strongly shapes biotic invasions on multiple spatial and temporal scales.

Past and present transportation events explain much of the variation in the distribution of alien species on different spatial scales.

Management regimes explain much of the variation in invasibility - particularly of human-dominated ecosystems.
Contextualisation of management based on phases identified by phase transition models.

Importance of rapid evolution for risk assessment systems and control efforts. Need for multi-scale management approaches.

Real-world experimentation and adaptive management

Landscape scale planning of invasive species management.

Transport pathways risk assessment and management.

Mainstreaming invasive species management in different economic sectors. 


\section{The production of target knowledge - Valuation of the impacts of invasive species}

Five different research approaches can be distinguished that have been or are used in invasion research to clarify target knowledge. These approaches differ in their research questions and methods, and have different implications for problem solving (Table 2). They are in the following shortly introduced in the order in which they appeared in time.

\subsection{Biological impact research}

The negative impacts of invasive species on native biota and ecosystems were discussed by Charles Darwin and other naturalists as early as the 19th century (Cadotte, 2006), and a wealth of case examples have been documented (e.g. Drake et al., 1989; Vitousek et al., 1987). However, only recently have frameworks for a more systematic research on impacts been suggested (Levine et al., 2003; Parker et al., 1999; Vitousek, 1990). Invasive species have been shown to substantially change ecosystem processes such as nutrient cycling, fire and other disturbances regimes, or hydrology (Levine et al., 2003; Mack et al., 2000). Besides impacts on ecosystem processes, the role of invasive species in native species decline and extinction is a major concern (Millennium Ecosystem Assessment, 2005). Invasive species have contributed to many species extinctions on oceanic islands (Reaser et al., 2007), but it is still debated to what extent this pattern can be generalised to continents (Gurevitch and Padilla, 2004). A major open question is whether and how impacts of alien species persist in the long-term (Hobbs et al., 2006; Strayer et al., 2006). Invasions may lead to habitat deterioration (Simberloff, 2006), or support ecosystem recovery after major habitat destruction (Kueffer and Daehler, 2008; Kueffer et al., 2007b; Safford and Jones, 1998). Recently, positive ecological effects of alien species on native biota (Rodriguez, 2006), and the usefulness of alien species for natural area management (D'Antonio and Meyerson, 2002; Zavaleta et al., 2001) have been emphasised.

\subsection{The native/alien debate}

A central tenant of invasion research is that the alien provenance of a species is relevant to predict and value their impacts. However, many authors have argued that the use of the native/alien dichotomy for judging a species is problematic because such an argumentation has close affinities to xenophobia or racism (Larson, 2005; Sagoff, 2005; Simberloff, 2003; Theodoropoulos, 2003; Warren, 2007). Nevertheless, given the weak predictability of the impacts of individual alien species, a precautionary approach has been proposed for invasive species risk assessment systems, which is based on the assumption that an alien species is problematic until proven otherwise (Simberloff, 2005; Wittenberg and Cock, 2001). Thus, the ongoing discussion among biologists, social scientists and philosophers on an appropriate use of the native/alien distinction as a proxy for understanding and predicting impacts of invasive species (Brown and Sax, 2004; Colautti and McIsaac, 2004; Kendle and Rose, 2000; Lodge and Shrader-Frechette, 2003; Shrader-Frechette, 2001) cannot easily be dismissed.

\subsection{Ecological risk assessment}

Ecological risk assessment is a procedure that evaluates the likelihood of negative ecological effects from exposure to a stressor (Simberloff, 2005). It consists of an assessment of the probability that a component of an ecosystem is exposed to a stressor and the characterisation of the ecological effects of the stressor on this ecosystem component (Andow and Hilbeck, 2004; Simberloff, 2005). In invasive species risk assessment systems, the risk of exposure is defined as the risk that a species 
is introduced, establishes in a new range and spreads into natural areas. For this component, risk assessment systems build on biological research on the invasiveness of alien species (Daehler et al., 2004; Pheloung et al., 1999; Wittenberg and Cock, 2001). In contrast, the formal characterisation of ecological effects has so far proven to be difficult, and explicit assessments of ecological effects are done only rarely or only in a qualitative manner through expert judgments (Andow and Hilbeck, 2004; Lodge et al., 2006; Mack and Barrett, 2002; Simberloff, 2005). The difficulties in characterising the impacts of biotic invasions in formalised systems are seen in the complexity of their impacts - they are often indirect, affect populations or communities rather than individuals, depend on the context of the invaded ecosystem, and show unpredictable temporal dynamics (Andersen et al., 2004b; Simberloff, 2005). Recently, spatially explicit modelling of biotic invasions has been proposed for a more quantitative assessment of exposure risks and corresponding ecological effects (Allen et al., 2006; Andersen et al., 2004a). An open question regarding current risk assessment systems is if and how economic or socioeconomic valuation (see below) should be included in the procedures (Andersen et al., 2004b).

\subsection{Economic valuation}

The monetary equivalent of the impacts of a biotic invasion is calculated through economic valuation. Estimates of the total costs stemming from biotic invasions are based on the current or projected future costs of all damages caused by alien species (Born et al., 2005; Olson, 2007; Pimentel et al., 2005). Sometimes the expenditure for controlling invasive species or other mitigation costs, e.g. treatment of allergic reactions to pollen of an invasive plant, are also included (Born et al., 2005; Pimentel et al., 2005). The monetary value of the ecological damages caused by alien species are usually calculated based on the concept of ecosystem services (Binimelis et al., 2007; Born et al., 2005; Charles and Dukes, 2007), i.e., the loss of ecosystem services through biotic invasions is derived from biological impact research (see above) (Charles and Dukes, 2007). Estimates of total costs stemming from biotic invasions for countries such as the U.S.A., Canada, Australia or Germany are typically of the order of more than US\$1 billion per year (Olson, 2007; Pimentel et al., 2005). However, to date such economic assessments are mainly based on expert knowledge and extrapolations from only a few well-documented aspects such as the annual expenditures to control a species in a particular area.

\subsection{Socioeconomic valuation}

Because many valuable things do not have a market price, or things are valuable for more than only economic reasons (Brun and Hirsch Hadorn, 2008), broader socioeconomic approaches to assess damages by biotic invasions are being developed (Binimelis et al., 2007). For instance, the damages to landscape aesthetics or the recreation value of nature have been estimated (Binimelis et al., 2007; Charles and Dukes, 2007), or the role of invasive species for poor people and developing countries is considered (Drake and Keller, 2004; Perrings, 2005). In socioeconomic valuation it is particularly important to recognise that alien species can have both positive and negative roles for people, and that the valuation of an alien species is dynamic and may change with time and context (Binimelis et al., 2007). Social sciences, ethics and historical research have provided a deeper understanding of socioeconomic valuation of invasive species issues in different contexts and in a historical time frame (e.g. Coates, 2007; Foster and Sandberg, 2004; Hall, 2003).

Living Reviews in Landscape Research

http://www. livingreviews.org/lrlr-2008-2 
Table 2: A categorisation of five different approaches that are used in invasion research to clarify target knowledge (see text for further explanation).

\begin{tabular}{|c|c|c|c|}
\hline & Research approach & Important insights & Link with application \\
\hline $\begin{array}{l}\text { Biological impact re- } \\
\text { search }\end{array}$ & $\begin{array}{l}\text { Biological research on im- } \\
\text { pacts on ecosystem proper- } \\
\text { ties and native biota. }\end{array}$ & $\begin{array}{l}\text { Single species can change } \\
\text { functioning of an ecosys- } \\
\text { tem. Invasive species are a } \\
\text { main threat factor for rare } \\
\text { species. In degraded ecosys- } \\
\text { tems invasive species can } \\
\text { have positive effects. }\end{array}$ & Awareness building \\
\hline Native/alien debate & $\begin{array}{l}\text { Theoretical consideration } \\
\text { of the implications of the } \\
\text { concept of alien origin in } \\
\text { invasive species research. }\end{array}$ & $\begin{array}{l}\text { The concept of alien origin } \\
\text { is problematic, but no al- } \\
\text { ternative, normative theory } \\
\text { about invasive species has } \\
\text { developed. }\end{array}$ & $\begin{array}{l}\text { It challenges the precau- } \\
\text { tionary approach in risk } \\
\text { assessment systems, and } \\
\text { highlights the importance } \\
\text { of an explicit debate about } \\
\text { the valuation of invasive } \\
\text { species. }\end{array}$ \\
\hline $\begin{array}{l}\text { Ecological risk assess- } \\
\text { ment }\end{array}$ & $\begin{array}{l}\text { Development of formal } \\
\text { procedures to assess the } \\
\text { risk that an alien species } \\
\text { spreads and leads to nega- } \\
\text { tive impacts. }\end{array}$ & $\begin{array}{l}\text { Difficulty to define a for- } \\
\text { malised and quantitative } \\
\text { approach to assess the im- } \\
\text { pacts of an invasive species. }\end{array}$ & Prevention \\
\hline Economic valuation & $\begin{array}{l}\text { Calculation of the monetary } \\
\text { value of the impacts of a } \\
\text { biotic invasion. }\end{array}$ & $\begin{array}{l}\text { Total costs of biotic inva- } \\
\text { sions are typical more than } \\
\text { US } \$ 1 \text { billion per year for a } \\
\text { country such as the U.S.A. }\end{array}$ & Awareness building \\
\hline $\begin{array}{l}\text { Socioeconomic valua- } \\
\text { tion }\end{array}$ & $\begin{array}{l}\text { Social sciences research on } \\
\text { stakeholder valuation of } \\
\text { invasive species. }\end{array}$ & $\begin{array}{l}\text { Valuation of invasive } \\
\text { species varies between } \\
\text { stakeholder groups and } \\
\text { context, and may include } \\
\text { both positive and negative } \\
\text { impacts. }\end{array}$ & $\begin{array}{l}\text { The need for a context- } \\
\text { dependent consideration of } \\
\text { stakeholder valuation. }\end{array}$ \\
\hline
\end{tabular}




\section{The production of transformation knowledge - Research that addresses the options for managing biotic invasions}

Management of invasive species can be divided into three different realms: i. prevention, ii. early detection and eradication, and iii. control of established alien species (Lodge et al., 2006; Wittenberg and Cock, 2001). Each of these three phases has different demands for research (Table 3).

\subsection{Prevention}

Prevention of introductions of potentially problematic alien species to a new area, or secondary releases of already introduced alien species within an area, builds on risk assessment systems and the regulation of the transportation of the identified problematic species (Kowarik, 2003; Simberloff, 2005; Wittenberg and Cock, 2001). Prevention is widely considered the most cost-effective way for managing invasive species (Baker et al., 2005; Lodge et al., 2006; Wittenberg and Cock, 2001). The application of risk assessment systems (Table 2) is confronted with a number of practical problems (Andersen et al., 2004a; Baker et al., 2005; Simberloff, 2005). In particular, the efficacy of expert-based risk assessments is very low. These assessments currently cover only a very small proportion of newly introduced species (Hulme, 2006; Lodge et al., 2006), because the assessment of a single species typically lasts for many months to several years (Lodge et al., 2006; Simberloff, 2005). Such assessments are also said to be highly vulnerable to political pressure (Simberloff, 2005). As an improvement, a precautionary approach has been proposed that treats all new alien species as problematic until proven otherwise (Simberloff, 2005; Wittenberg and Cock, 2001).

Traditionally, risk assessments have been implemented at a national or transnational level. However, the uncertainties of risk assessments may be reduced when they are performed at smaller local scales, e.g. on a regional (Radosevich et al., 2005) or habitat scale (cf. Lodge et al., 2006), or specifically address particular introduction pathways (Hulme, 2006). Pathway risk analyses have for instance been developed for the trade of untreated wood (cf. Simberloff, 2005). Context specific risk assessments allow for a comprehensive risk management, i.e., different management measures are combined to optimize the cost-benefit balance (Hallman, 2007). The risk management of Mediterranean fruit fly introductions through trade of pink tomatoes from Northern Africa to the U.S. combines regulations about the origin of the product, restrictions on the seasons when trade is allowed, and a number of measures during production and transport (Hallman, 2007). Increased context specificity allows also to better shape research according to the needs of particular actors, such as in the cases of marine shipping (Minton et al., 2005), or the horticulture and pet industries (e.g. Perrings et al., 2005; Reichard and White, 2001).

Besides risk assessment systems, market mechanisms such as tradeable risk permits (Horan and Lupi, 2005), taxes (Knowler and Barbier, 2005; Perrings et al., 2005), or the implementation of the polluters pay principle (Perrings et al., 2005), have been discussed as alternative policy instruments for prevention.

\subsection{Early detection and eradication}

Eradication is very difficult, because literally all reproductive individuals have to be removed, and the risk of re-invasion has to be zero (Genovesi, 2007; Myers et al., 2000). Cost-effective eradication of an invasive species is therefore only possible in a very early phase of an invasion when the population size and infested areas are still small. It is generally assumed that after prevention early detection of newly introduced species and immediate action to eradicate the species before it spreads should be the second priority in invasive species management (Genovesi, 2007; Lodge et al., 2006; Wittenberg and Cock, 2001). However, the detection of small populations in an early stage of an invasion is particularly challenging and potentially costly (Hulme, 2006; Lodge et al., 2006).

Living Reviews in Landscape Research

http://www. livingreviews.org/lrlr-2008-2 
Research that combines statistical and biological considerations can optimize surveying methods (Baker et al., 2005; Hulme, 2006; Rew et al., 2005), e.g. by focusing surveys on the areas where the appearance of new invasive species is most likely. Both environmental factors and human activities can help to predict the likelihood of new appearances (Buchan and Padilla, 2000). Search theory, a sophisticated mathematical approach, can help to define the most efficient search strategy (Cacho et al., 2006; Mehta et al., 2007). Early detection may also profit from new technologies such as remote sensing (Hulme, 2006; Lodge et al., 2006) or molecular biology techniques (Baker et al., 2005; Lodge et al., 2006). Finally, successful early detection depends on socioeconomic factors, i.e., the necessary awareness and financial and institutional capacity needs to be established so that professionals from all relevant agencies as well as volunteers can be effectively involved (Genovesi, 2007; Hegamyer et al., 2003; Hulme, 2006; Lodge et al., 2006; Wittenberg and Cock, 2001).

\subsection{The control of invasive species}

\section{Planning}

When eradication of an invasive species is not possible, an appropriate strategy to contain the spread of the species is defined (control of an invasive species) (Genovesi, 2007; Lodge et al., 2006; Myers et al., 2000; Wittenberg and Cock, 2001). Typically, priority areas are identified where invasive species are kept below a certain threshold through continuous management (Mack and Lonsdale, 2002; Myers et al., 2000; Thomas and Reid, 2007). Every successful control programme has to agree on clear objectives (Anderson et al., 2003; Baker et al., 2005; Genovesi, 2007; Wittenberg and Cock, 2001). A number of decision aid tools have been developed to support the setting of appropriate objectives for control programmes. These tools may for instance help to define priority species and areas (Hiebert, 1996; Tassin et al., 2006; Wittenberg and Cock, 2001), or acceptable levels for the population density of an invasive species - a concept that has a long tradition in agricultural weed management and biological control (Hulme, 2006; Smith et al., 2006; Thomas and Reid, 2007). Often a detailed consideration of the stakeholders' valuation of a management attempt is necessary. The socioeconomic valuation of management measures, including prevention (Finnoff et al., 2007), may compare the costs and benefits of different management scenarios (cost-benefit analysis), or the costs and effectiveness to achieve a certain goal through different strategies (cost-effectiveness analysis) (Binimelis et al., 2007; Born et al., 2005). Thereby the valuation of the positive and negative aspects of a management strategy may vary considerably between stakeholder groups (Bremner and Park, 2007; Veitch and Clout, 2001).

A major recent research effort has focused on a detailed modelling of the costs and benefits of different management strategies by combining socioeconomic valuation with information on the biology and management options of a particular species. Such bioeconomic modelling helps to identify the optimal control technique (Baker et al., 2005), and to define the conditions under which it is still economic to eradicate a species (Regan et al., 2006) or the optimal threshold population density of a species that is contained (Anderson et al., 2003). Bioeconomic models are often based on sophisticated biological models, that include, for instance, multitrophic biotic interactions (Gutierrez and Regev, 2005) or spatially explicit spread modelling (Olson, 2007). Similarly, the economic models may vary from simple economic to complex socioeconomic valuation of management strategies (see above). A range of control techniques from mechanical, chemical or biological control to habitat management approaches may be considered (see below) (Olson, 2007), as well as different management contexts and scales from local natural area management to nationwide efforts (Born et al., 2005; Olson, 2007). 


\section{Control techniques}

Control techniques can be classified into mechanical, chemical and biological control and habitat management (Lodge et al., 2006; Myers and Bazely, 2003; Wittenberg and Cock, 2001). Successful control programs depend often on the experience and knowledge of practitioners (Bossard et al., 2000; Tu et al., 2001). Mechanical control encompasses all actions that physically destroy an invasive species, e.g. the pulling out of a plant by hand or shooting of an animal. Chemical control measures target invasive species through the application of a pesticide. Major obstacles are the risk of an environmental contamination of natural areas with the chemical, non-target effects on native species, or the evolution of pesticide-resistance by the invasive species (Baker et al., 2005; Lodge et al., 2006; Myers and Bazely, 2003; Wittenberg and Cock, 2001). In the case of biological control a natural enemy such as a herbivore or pathogen is introduced with the aim that the introduced organism controls the invasive species (Babendreier, 2007; Messing and Wright, 2006; Mack and Barrett, 2002; Thomas and Reid, 2007). Major risks of the introduction of an (alien) organism in biological control programs are non-target effects on the native biota. Finally, habitat management targets invasive species through the manipulation of environmental characteristics of the invaded habitat, e.g. through prescribed fire, planting of native species, or the alteration of soil conditions (Myers and Bazely, 2003; Wittenberg and Cock, 2001). Habitat management strategies are closely linked to habitat restoration (D'Antonio and Meyerson, 2002; Zavaleta et al., 2001). A habitat perspective in invasive species removal is important to avoid negative impacts of invasive species control programmes, e.g. because of habitat disturbance or of the removal of alien species that play an important role for the native biota or ecosystem (Anderson et al., 2003; Myers et al., 2000; Zavaleta et al., 2001).

\section{The wider socio-political context}

Successful control programmes depend on the concerted long-term action of many agencies and the support of many stakeholders (Anderson et al., 2003; Genovesi, 2007; Myers et al., 2000; Wittenberg and Cock, 2001). A holistic approach to form such an alliance is social marketing (Wittenberg and Cock, 2001). Social marketing is based on an analysis of the social, cultural, political and economic context of the invasion, and aims at forming a partnership among all relevant agencies and stakeholders. Based on a thorough understanding of the conflicts of interests and values (target knowledge) and the options and constraints of the actors (transformation knowledge) in a particular management context, control strategies are defined that are thought to be effective and acceptable to all stakeholders.

Living Reviews in Landscape Research 
Table 3: A categorisation of three different management approaches, their links with systems and target knowledge, and their needs for transformation knowledge (see text for further explanation).

\begin{tabular}{|c|c|c|c|c|}
\hline & $\begin{array}{l}\text { Management ap- } \\
\text { proach }\end{array}$ & Research needs & $\begin{array}{l}\text { Relevant systems } \\
\text { knowledge }\end{array}$ & $\begin{array}{l}\text { Relevant target } \\
\text { knowledge }\end{array}$ \\
\hline Prevention & $\begin{array}{l}\text { Prevention of the } \\
\text { introduction of po- } \\
\text { tentially new invasive } \\
\text { species at borders } \\
\text { or through the man- } \\
\text { agement of specific } \\
\text { transport pathways }\end{array}$ & $\begin{array}{l}\text { Risk assessment sys- } \\
\text { tems } \\
\text { Context-dependent } \\
\text { pathway risk man- } \\
\text { agement based on } \\
\text { systems approach and } \\
\text { integrated into appro- } \\
\text { priate institutional } \\
\text { contexts } \\
\text { Market mechanism } \\
\text { to support preventive } \\
\text { measures }\end{array}$ & $\begin{array}{l}\text { Plant invasiveness } \\
\text { Transportation path- } \\
\text { ways }\end{array}$ & $\begin{array}{l}\text { Ecological risk assess- } \\
\text { ment } \\
\text { Clarification of na- } \\
\text { tive/alien debate } \\
\text { (Socio)economic valu- } \\
\text { ation of impacts }\end{array}$ \\
\hline $\begin{array}{l}\text { Early detection } \\
\text { and eradication }\end{array}$ & $\begin{array}{l}\text { Early detection of } \\
\text { newly introduced } \\
\text { invasive species and } \\
\text { rapid response for } \\
\text { eradication }\end{array}$ & $\begin{array}{l}\text { Efficient search } \\
\text { strategies } \\
\text { Appropriate institu- } \\
\text { tional mechanisms for } \\
\text { rapid response }\end{array}$ & $\begin{array}{l}\text { Plant invasiveness } \\
\text { Habitat invasibility } \\
\text { Phase transition } \\
\text { models }\end{array}$ & $\begin{array}{l}\text { Ecological risk assess- } \\
\text { ment }\end{array}$ \\
\hline Control & $\begin{array}{l}\text { Containment of inva- } \\
\text { sive species through } \\
\text { control measures and } \\
\text { according to a control } \\
\text { strategy }\end{array}$ & $\begin{array}{l}\text { Cost-benefit analysis } \\
\text { of different control } \\
\text { strategies } \\
\text { Effective control mea- } \\
\text { sures } \\
\text { Social marketing }\end{array}$ & $\begin{array}{l}\text { Plant invasiveness } \\
\text { Habitat invasibility } \\
\text { Landscale ecology } \\
\text { Multifactorial case } \\
\text { studies } \\
\text { Land use science }\end{array}$ & $\begin{array}{l}\text { Biological impact } \\
\text { research } \\
\text { (Socio)economic valu- } \\
\text { ation of impacts }\end{array}$ \\
\hline
\end{tabular}




\section{Discussion}

We have shown that over the past decades a broad range of different research approaches has emerged in order to produce systems, target and transformation knowledge for invasive species management. We can ultimately not judge if current invasion research produces effective knowledge for problem-solving, because this has to be assessed through deliberations among the experts and stakeholders involved in the issue (boundary management). However, we summarize in the following how invasion research has evolved in the past and point out potential future transformations of the research field. Then, we discuss the forms of boundary management that were (not) in place to frame adequate research questions about processes, values and practices for effective problem-solving. We conclude by suggesting a number of achievements and limitations of how problem-orientation evolved in invasion research, and relate these to the forms of boundary management that were in place or missing.

\subsection{The evolution of invasion research: The search for an adequate fram- ing of problem-oriented research on biotic invasions}

\section{The evolution of research on systems knowledge}

Since the emergence of the research field of invasion biology in the late 1950s, a main motivation behind the research of most involved scientists was to contribute to the solving of a perceived societal problem (Davis, 2006). In particular, the invasion classic by Elton (1958) and the first SCOPE research program (Drake et al., 1989) had a clear conservation focus. Initially, most research was focused on producing systems knowledge. Thereby the assumption was that the causal dynamics of biotic invasions could not be fully understood by simply applying established ecological principles. Rather than initiating, for instance, landscape ecological research on invasion spread, novel guiding research questions were defined that were thought to be adequate for problem-solving. In the beginning these questions focused on the traits of problematic invasive species (invasiveness), and the characteristics of habitats that are vulnerable to invasions (invasibility) ("classical model", Table 1). With time it proved that the focus of these initial guiding questions was too narrow, and new aspects had to be addressed, that were integrated into the established framework of invasion research (e.g. "phase transition models", Table 1). Currently, concepts such as invasive species, invasiveness, invasibility, propagule pressure and invasion phases provide a theoretical framework that is rigid enough to sustain biological invasion research as an independent research field, i.e., research papers on biotic invasions address primarily such invasion specific concepts, rather than, for instance, general ecological principles and their application to biotic invasions.

The future development of the research field will reveal whether research on biotic invasions will be able to maintain a separate niche besides general ecological research or other related research fields such as weed science, restoration ecology, global change biology or conservation biology, which increasingly also study biotic invasions from their perspectives. For instance, it has recurrently been argued that invasion research is artifically dissociated from general ecology, and the need for a separate conceptual framework has been questioned (Davis, 2006; Davis et al., 2001). In fact, general ecological research on biotic invasions has recently gained momentum ("natural experiments", Table 1). It is not evident whether invasions of alien species will in the future still be considered a separate issue from other colonisation and migration processes that occur with global change. Thereby the fate of the research field will on the one hand depend on how well biological invasion research will be able to synthesise existing knowledge and integrate neglected processes, such as spatial processes (compare "landscale ecology", Table 1), into an invasion specific theoretical framework. On the other hand, it will depend on the assessment by the relevant experts and stakeholders of the adequacy of current biological invasion research for problem-solving. Whether biotic invasions are studied as unique processes, or based on the frameworks of general

Living Reviews in Landscape Research

http://www.livingreviews.org/lrlr-2008-2 
ecology, weed science, restoration ecology or conservation biology, respectively, will have important ramifications on how the problem of invasive species is valued and managed.

In the early 2000s, social sciences research revisited earlier research (see Kowarik, 2003) on the role of human agency in biotic invasions ("vector science" and "land use science", Table 1), and this has further dynamised the framing of research questions on the causal dynamics of biotic invasions. It proved that human agency is a critical factor in biotic invasions, which challenged the legitimacy of purely biological invasion research. The future of invasion research will show to what extent the integration of social sciences research will transform the field. It may be that existing research fields at the boundary of ecological and social sciences such as urban ecology (cf. Davis, 2006), ethnoecology (Clayton, 2003; Drake and Hunt, 2007; McDowall, 1994), or research at the boundary between epidemiology and ecology (compare Wilcox and Kueffer, 2008) may contribute to an integrative framework. It has been suggested that social sciences research on land-use change may have the potential to interpret many ecological global change phenomena including biotic invasions from a social science perspective (Jay and Morad, 2006; Robbins, 2004; Schneider and Geoghegan, 2006). Again, such transformations of the research field would not only have consequences for research but also for problem-solving.

\section{The evolution of research on target knowledge}

The valuation of impacts of invasive species was initially based only on biological research on ecological effects of invasive species on ecosystem properties and native biota ("biological impact research", Table 2). This was problematic because normative statements were based solely on empirical studies without explicitly discussing the underlying normative assumptions. It was basically assumed that any strong effect or even simply the presence of an alien species is per se problematic. Biological impact research was only partly able to differentiate whether invasive species are a driver or result of ecological change (Didham et al., 2005), rarely considered potential positive effects, and was not in a position to develop a framework that allowed weighting positive and negative impacts. More recently, concepts from other research fields have been applied to the issue that allow for an explicit valuation of impacts. These inputs came from four different backgrounds, namely philosophy ("native/alien debate", Table 2), risk research ("risk assessment", Table 2), (ecological) economics ("economic valuation", Table 2), and social sciences research ("socioeconomic valuation", Table 2). However, these imported concepts have been applied to the issue without considering the particular challenges involved in valuating invasive species, but valuation concepts need to be tailored to the context of a particular issue (compare e.g. Brun and Hirsch Hadorn, 2008). Conceptual debates about the valuation of invasive species ("native/alien debate", Table 2) have not led to a new conceptual understanding of valuation beyond criticising current normative thinking. In contrast, social sciences research in the field of restoration ecology has worked towards a new normative thinking about attempts to restore or design nature (e.g. Gobster and Hull, 2000; Higgs, 2003). Invasion research on target knowledge awaits new integrative concepts that synthesise ecological knowledge and normative thinking.

\section{The evolution of research on transformation knowledge}

The production of transformation knowledge is characterised by a tension between on the one hand producing technical knowledge and "tools" that are tailored to the existing options of actors, and on the other hand identifying strategies that allow to fundamentally transform the management context. In the first case, problem-oriented research is typically applied research in the sense that research questions are based on an established understanding of the management issue and on the existing institutional framework. To date, much of the invasion research on transformation knowledge is such applied research. Based on a conceptual model that structures management into the three phases of prevention, early detection and eradication, and control, management tasks 
are divided up among existing agencies and these in turn define their immediate research needs based on existing invasion research and expertise (Table 3). For instance, prevention depends on effective risk assessment systems and techniques to detect new potentially invasive alien species at borders or minimize secondary releases of already introduced invasive species in the region, or credible target knowledge to inform public awareness campaigns.

In contrast, research on transformation knowledge may also target fundamental changes of the current framing and institutional setup of invasion species management. However, it seems that invasion research has so far not explicitly investigated if current management approaches are appropriate or if they need to be reconsidered fundamentally. Although it has recurrently been emphasised that current institutional setups are not appropriate to deal with invasions that happen on multiple spatial scales (Lodge et al., 2006), there has been no research on how to fundamentally adapt governance of invasive species issues in contrast to other environmental issues (e.g. Folke et al., 2005; Hirsch Hadorn et al., 2002). Invasion research on transformation knowledge may profit from transferring institutional innovations from other management fields to the issue of invasive species. For instance, rapid response teams that have been in place for a long time to respond to emergencies such as wild fires, chemical, biological or radioactive spills, or medical emergencies have been discussed as a model for invasive species eradication programs (Curt Daehler, pers. comm.).

\section{The co-production of systems, target and transformation knowledge}

We have discussed research on systems, target and transformation knowledge separately, and we think that this decomposition of research questions is useful because the three forms of knowledge are categorically different. However, we have also emphasised that the three forms of knowledge are interrelated. Innovation in one realm has consequences for the other knowledge forms. For instance, a move towards landscape-scale research on systems knowledge may initiate a shift towards largescale management approaches. Alternatively, innovations in research on target knowledge will influence stakeholders' valuation of invasive species, which will feed back on research on systems knowledge that attempts to understand human motivation in order to explain invasion processes.

In a number of cases, close affinities between research on systems, target and transformation knowledge have evolved (compare Tables 1, 2, and 3). For instance, research on plant invasiveness is closely linked to the development of risk assessment systems. Biological impact research, economic valuation and awareness building form another cluster. Bioeconomic modelling builds on (socio)economic valuation, landscape ecology of invasion spread and transformation knowledge related to control techniques. Finally, a particularly interesting case is the emergence of vector science because it represents at once a fundamental transformation of research on systems and transformation knowledge.

\section{Contextualisation - A fundamental process for enhancing problem-orientation}

Across all three types of knowledge - systems, target and transformation knowledge - research has with time become more specific to particular contexts in order to reduce the scientific and management complexities. Research on systems knowledge has moved from identifying general traits of invasive species and invaded habitats ("classical model", Table 1) to study particular invasion phases ("phase transition models", Table 1), transport pathways ("vector science", Table 1), or invasion cases ("multifactorial case studies", Table 1). Research on target knowledge has shifted from a general to a context-specific assessment of the impacts of an invasive species. For instance, risk assessments became more specific to particular transport pathways, regions or habitats. Economic valuation has focused increasingly on supporting particular management decisions. The general discussion about the validity of the alien/native dichotomy has gained clarity through research on the socioeconomic valuation of particular management cases. In the case of

Living Reviews in Landscape Research

http://www. livingreviews.org/lrlr-2008-2 
transformation knowledge, prevention shifted from general to pathway specific approaches, and control efforts are designed for particular species and habitats.

\subsection{Forms of boundary management}

The adequacy of the framing of research questions for problem-solving in invasion research has been continuously debated in the field. A wealth of concept articles has been published, as well as articles that discuss the relevance of research for management and the priority needs for future research (e.g. Drake et al., 1989; Lodge et al., 2006; Mack et al., 2000; Meyerson and Mooney, 2007; Nentwig, 2007; Simberloff et al., 2005). However, these articles were mostly written by groups of (academic) scientists, and were not based on explicit boundary management among non-academic and academic experts and stakeholders. There were also attempts to assess the scientific quality of invasion research through peer-review processes that consider the outreach to management (Millennium Ecosystem Assessment, 2005; Roberts and Pullin, 2007; Wilson et al., 2007). But again, these were intra-scientific assessments, and primarily the credibility and to some extent the relevance of research but not its legitimacy were considered.

More generally, boundary management in invasion research has happened so far mostly through expert-driven processes, or informal and unstructured interactions among experts and stakeholders (e.g. communities of practice, trading zones; see below), while formal processes of boundary management (e.g. transdisciplinary research, participatory processes; see below) have been rare. The main informal and formal processes of boundary management in invasion research are shortly introduced in the following.

\section{Informal processes of boundary management}

A strength of invasion research are long-term informal but continuous interactions that have evolved among scientists and managers. Such interactions among scientists and practitioners with different backgrounds but a common interest in a thematically restricted domain of problem-solving issues are sometimes called communities of practice (Roux et al., 2006). The World Conservation Union (IUCN) for instance has established an Invasive Species Specialist Group that is composed of a wide range of experts both from academia and management and that interacts daily through a public mailing-list (Clout and Poorter de, 2005). The epistemological interactions in such communities of practice are often facilitated through boundary objects (Cash et al., 2003; Hellström and Jacob, 2003; Pohl and Hirsch Hadorn, 2007). A boundary object is an epistemological object that is plastic enough so that different experts can interprete it differently for their epistemological context, yet robust enough to maintain a common meaning among different expert groups (Star and Griesemer, 1989). The concept of an invasive alien species is a good example of a boundary object. Different experts have strongly differing and even contradictory understandings of an invasive alien species (e.g. Colautti and McIsaac, 2004) but are nevertheless able to fruitfully interact.

Informal collaborations that remain within a scientific context may be called trading zones (Galison, 1999). Trading zones are research contexts that facilitate the development of integrative research approaches that transgress a single scientific (sub)discipline. In the case of trading zones there are typically two or more groups of experts that depend on specific inputs from each other. For instance the development of bioeconomic models (see above) may be interpreted as a trading zone, where economists and ecologists depend on each others' expertise. Either ecologists develop models that they publish in ecological journals based on inputs from economists (e.g. Hastings et al., 2006), or vice versa (e.g. Olson, 2007). Thereby one expert group may try to direct research in the other field of expertise according to its needs for specific expert inputs (compare e.g. Bossenbroek et al., 2005). Trading zones are a common form of interdisciplinary collaboration, and exist for instance also at the interface between ecology and global change research (Kwa, 2005). 


\section{Formal processes of boundary management}

Boundary organisations, i.e., agencies that are situated at the boundary between science and management, are appropriate institutional settings to facilitate formal processes of boundary management (Cash et al., 2003; Hellström and Jacob, 2003). The most prominent example in the case of invasive species management is the Global Invasive Species Programme (GISP, www.gisp.org). The GISP has the mission to synthesis problem-oriented research (Mooney et al., 2005), raise awareness about biotic invasions, document and disseminate information, and link relevant agencies. There also exist a number of geographically and thematically restricted boundary organisations (Clout and Poorter de, 2005; Meyerson and Mooney, 2007), for instance the Mountain Invasion Research Network (MIREN, www.miren.ethz.ch) that networks mountain ecosystem and invasive species managers and invasion biologists (Dietz et al., 2006).

However, to date these boundary organisations in the context of invasive species management mainly network agencies and disseminate information, but they do not invest in establishing structured boundary management processes. For instance, to our knowledge there are to date no transdisciplinary research projects on biotic invasions. In transdisciplinary research the framing of adequate research questions is itself a topic of the research project (Pohl and Hirsch Hadorn, 2007). Participatory methodologies that guide deliberations among stakeholders have also rarely been employed in invasion research, with the notable exceptions of a few examples, such as the use of scenario planning (Binimelis et al., 2007; Chapman et al., 2001; Higgins et al., 1997), multicriteria assessment (Binimelis et al., 2007; Cook and Proctor, 2007), or agent based modelling of conflicts of interests (Macpherson et al., 2006). 


\section{Conclusions}

We have argued that problem-oriented research may assist problem-solving in three ways by, respectively, analysing casual relationships (systems knowledge), clarifying conflicts of interests and values (target knowledge), or contributing to the development of appropriate means for action (transformation knowledge). We have shown that an interest in all three knowledge forms has evolved in invasion research. In the beginning, research on systems knowledge dominated the field, but increasingly the three knowledge forms have been treated more equally. We interpret this evolution towards a more balanced research focus on systems, target and transformation knowledge as an important learning process that has enhanced the effectiveness of the research field. The increased interdisciplinarity and context-specificity of invasion research are in our view two other aspects that have emerged through learning and are critical for the effectiveness of problem-oriented research (compare Kueffer, 2006; Pohl and Hirsch Hadorn, 2007).

In contrast to these advances, we see in particular three shortcomings of the field that hinder the effectiveness of invasion research. First, the existing theoretical frameworks are currently only partly able to integrate natural and social sciences research on the processes underlying invasions. For instance, research on biotic invasions needs to be reconsidered in the context of global change, or human agency has to be incorporated into theoretical frameworks. In the case of transportation processes, vector science has made first important steps towards an integrative framework, but other invasion phases are not covered by this approach. Thereby it may be fruitful to revisit research approaches pre-dating the formation of an explicit research field in the late 1950s, such as the European tradition of 'adventive floristics' that had in the late 19th and early 20th centuries already considered the role of human agency in biotic invasions (cf. Kowarik, 2003). Second, a clarification of the normative thinking about alien plant invasions is needed as discussed in the section on the native/alien debate. Third, research on transformation knowledge has so far not fundamentally challenged the existing conceptual framing and institutional setup of invasive species management. However, because biotic invasions are a novel type of complex, multi-scale socioecological processes, that involve a large number of different actors and stakeholders, institutional innovations are needed.

We postulate that these three shortcomings can only be overcome through formal boundary management processes such as transdisciplinary research or participatory processes, which are to date scarce in invasion research. This is because in all three cases, innovations may substantially challenge the problem understanding both in the scientific and management contexts, and power relations among experts and stakeholders may be fundamentally reshaped (cf. Elzinga, 2008). Such inherently post-normal problem framing processes, where both epistemological and social boundaries are fundamentally challenged, require boundary management processes that integrate not only thinking from different disciplines, but also non-academic perspectives. Boundary management must also explicitly address the reshuffling of power relations among experts and stakeholders through processes that are perceived to be fair and impartial by all participants. Over the past decades, transdisciplinary scholarship has developed appropriate methodologies for such processes (see e.g. www.transdisciplinarity.ch or www.anu.edu.au/iisn).

In summary, the long-term problem-orientation of the field of invasion research has allowed for a number of innovations that have significantly enhanced the effectiveness of the science for management. However, for the development of the field, research and management may have to be substantially reconfigured, and this will need structured and explicit boundary management processes such as transdisciplinary research. 


\section{Acknowledgements}

CK was supported by USDA Cooperative Research, Education, and Extension Service Award Grant \# 2006-35320-17360 to C.C. Daehler. We thank Curt Daehler, Jake Alexander and two anonymous reviewers for helpful comments on earlier versions of the article, Jake Alexander for revising the language, and Eva Schumacher for assistance with the preparation of the figures. 


\section{References}

Allen, C.R., Johnson, A.R., Parris, L. (2006), "A Framework for Spatial Risk Assessments: Potential Impacts of Nonindigenous Invasive Species on Native Species", Ecology and Society, 11(1): 39. URL (cited on 23 June 2008): http://www.ecologyandsociety.org/vol11/iss1/art39/. 5.3

Alpert, P., Bone, E., Holzapfel, C. (2000), "Invasiveness, invasibility and the role of environmental stress in the spread of non-native plants", Perspectives in Plant Ecology, Evolution and Systematics, 3(1): 52-66, doi:10.1078/1433-8319-00004. 4.1

Andersen, M.C., Adams, H., Hope, B., Powell, M. (2004a), "Risk analysis for invasive species: general framework and research needs", Risk Analysis, 24(4): 893-900, doi:10.1111/j.02724332.2004.00487.x. 5.3, 6.1

Andersen, M.C., Adams, H., Hope, B., Powell, M. (2004b), "Risk assessment for invasive species", Risk Analysis, 24(4): 787-793, doi:10.1111/j.0272-4332.2004.00478.x. 5.3

Anderson, G.L., Delfosse, E.S., Spencer, N.R., Presser, C.W., Richard, R.D. (2003), "Lessons in developing successful invasive weed control programs", Journal of Range Management, 56(1): 2-12. 6.3, 6.3, 6.3

Andow, D.A., Hilbeck, A. (2004), "Science-based risk assessment for nontarget effects of transgenic crops", BioScience, 54(7): 637-649. 5.3

Asner, G.P., Vitousek, P.M. (2005), "Remote analysis of biological invasion and biogeochemical change", Proceedings of the National Academy of Sciences, 102(12): 4383-4386, doi: 10.1073/pnas.0500823102. 4.5

Babendreier, D. (2007), "Pros and Cons of Biological Control", in Biological Invasions, (Ed.) Nentwig, W., pp. 403-418, Berlin (Springer). 6.3

Baker, H.G. (1974), "The evolution of weeds", Annual Review of Ecology and Systematics, 5: 1-24, doi:10.1146/annurev.es.05.110174.000245. 4.1

Baker, R., Cannon, R., Bartlett, P., Barker, I. (2005), "Novel strategies for assessing and managing the risks posed by invasive alien species to global crop production and biodiversity", Annals of Applied Biology, 146(2): 177-191, doi:10.1111/j.1744-7348.2005.040071.x. 6.1, 6.2, 6.3, 6.3

Bammer, G. (2005), "Integration and Implementation Sciences: Building a New Specialization", Ecology and Society, 10(2): 6. URL (cited on 23 June 2008):

http://www.ecologyandsociety.org/vol10/iss2/art6/. 1, 2

Becker, E. (2002), "Transformations of social and ecological issues into transdisciplinary research", in Knowledge for Sustainable Development: An Insight into the Encyclopedia of Life Support Systems, Volume III, pp. 949-963, Oxford, UK (UNESCO Publishing / Eolss Publishers). 2

Becker, E., Jahn, T. (Eds.) (2006), Soziale Ökologie: Grundzüge einer Wissenschaft von den gesellschaftlichen Naturverhältnissen, Frankfurt am Main (Campus). 2, 2

Bergmann, M., Brohmann, B., Hoffmann, E., Loibl, M.C., Rehaag, R., Schramm, E., Voß, J.-P. (2005), "Quality Criteria of Transdisciplinary Research. A Guide for the Formative Evaluation of Research Projects", ISOE Studientexte, No. 13, Frankfurt am Main (ISOE). 2 
Binimelis, R., Born, W., Monterroso, I., Rodriguez-Labajos, B. (2007), "Socio-Economic Impact and Assessment of Biological Invasions", in Biological Invasions, (Ed.) Nentwig, W., pp. 331347, Berlin (Springer). 5.4, 5.5, 6.3, 7.2

Blumenthal, D. (2005), "Interrelated causes of plant invasion", Science, 310(5746): 243-244, doi: 10.1126/science.1114851. 4.4

Bocking, S. (2004), Nature's Experts: Science, Politics, and the Environment, New Brunswick, NJ (Rutgers University Press). Related online version (cited on 11 July 2008):

http: //books.google.com/books?id=RXD8I3wRmMUC. 1, 2

Born, W., Rauschmayer, F., Bräuer, I. (2005), "Economic evaluation of biological invasions - a survey", Ecological Economics, 55(3): 321-336, doi:10.1016/j.ecolecon.2005.08.014. 5.4, 6.3

Bossard, C.C., Randall, J.M., Hoshovsky, M.C. (Eds.) (2000), Invasive Plants of California's Wildlands, Berkeley (University of California Press). Related online version (cited on 11 July 2008):

http://books.google.com/books?id=ihE5XKaEQXUC. 6.3

Bossenbroek, J.M., McNulty, J., Keller, R.P. (2005), "Can ecologists heat up the discussion on invasive species risk?", Risk Analysis, 25(6): 1595-1597, doi:10.1111/j.1539-6924.2005.00697.x. 7.2

Bradley, B.A., Mustard, J.F. (2006), "Characterizing the landscape dynamics of an invasive plant and risk of invasion using remote sensing", Ecological Applications, 16(3): 1132-1147, doi: 10.1890/1051-0761(2006)016[1132:CTLDOA]2.0.CO;2. 4.5

Brand, K.-W. (Ed.) (2000), Nachhaltige Entwicklung und Transdisziplinarität, Berlin (Analytica). 2

Bremner, A., Park, K. (2007), "Public attitudes to the management of invasive non-native species in Scotland", Biological Conservation, 139(3-4): 306-314, doi:10.1016/j.biocon.2007.07.005. 6.3

Broennimann, O., Treier, U.A., Müller-Schärer, H., Thuiller, W., Peterson, A.T., Guisan, A. (2007), "Evidence of climatic niche shift during biological invasion", Ecology Letters, 10(8): 701-709, doi:10.1111/j.1461-0248.2007.01060.x. 4.3

Brook, I. (2003), "Making here like there: place attachment, displacement and the urge to garden", Ethics, Place \& Environment, 6(3): 227 - 234, doi:10.1080/1366879042000200651. 4.6

Brown, J., Sax, D.F. (2004), "An essay on some topics concerning invasive species", Austral Ecology, 29(5): 530-536, doi:10.1111/j.1442-9993.2004.01340.x. 5.2

Brun, G., Hirsch Hadorn, G. (2008), "Ranking policy options for sustainable development", Poiesis \& Praxis, 5(1): 15-31, doi:10.1007/s10202-007-0034-y. 5.5, 7.1

Buchan, L.A.J., Padilla, D.K. (2000), "Predicting the likelihood of Eurasian watermilfoil presence in lakes, a macrophyte monitoring tool", Ecological Applications, 10(5): 1442-1455, doi: 10.1890/1051-0761(2000)010[1442:PTLOEW]2.0.CO;2. 6.2

Cacho, J.O., Spring, D., Pheloung, P., Hester, S. (2006), "Evaluating the feasibility of eradicating an invasion", Biological Invasions, 8(4): 903-917, doi:10.1007/s10530-005-4733-9. 6.2

Cadotte, M.W. (2006), "Darwin to Elton: Early ecology and the problem of invasive species", in Conceptual ecology and invasion biology: reciprocal approaches to nature, (Eds.) Cadotte, M.W., McMahon, S.M., Fukami, T., pp. 15-33, Dordrecht, The Netherlands (Springer). 3.2, 5.1

Living Reviews in Landscape Research

http://www. livingreviews.org/lrlr-2008-2 
Cadotte, M.W., McMahon, S.M., Fukami, T. (Eds.) (2006a), Conceptual ecology and invasion biology: reciprocal approaches to nature, Dordrecht, The Netherlands (Springer). 4.3

Cadotte, M.W., Murray, B.R., Lovett-Doust, J. (2006b), "Ecological patterns and biological invasions: using regional species inventories in macroecology", Biological Invasions, 8(4): 809-821, doi:10.1007/s10530-005-3839-4. 4.1

Callaway, R.M., Maron, J.L. (2006), "What have exotic plant invasions taught us over the past 20 years?", Trends in Ecology \&G Evolution, 21(7): 369-374, doi:10.1016/j.tree.2006.04.008. 4.3, 4.4

Cash, D.W., Clark, W.C., Alcock, F., Dickson, N.M., Eckley, N., Guston, D H, Jäger, J., Mitchell, R.B. (2003), "Knowledge systems for sustainable development", Proceedings of the National Academy of Sciences, 100(14): 8086-8091, doi:10.1073/pnas.1231332100. 1, 2, 2, 2, 7.2, 7.2

Chapman, R.A., Le Maitre, D.C., Richardson, D.M. (2001), "Scenario planning: understanding and managing biological invasions in South Africa", in The Great Reshuffling: Human Dimensions of Invasive Alien Species, (Ed.) McNeely, J.A., pp. 195-208, Gland, Switzerland and Cambridge, UK (IUCN). 7.2

Charles, H., Dukes, J.S. (2007), "Impacts of Invasive Species on Ecosystem Services", in Biological Invasions, (Ed.) Nentwig, W., pp. 217-237, Berlin (Springer). 5.4, 5.5

Clayton, N. (2003), "Weeds, people and contested places", Environment and History, 9(3): 301331. 7.1

Clout, M.N., Poorter de, M. (2005), "International initiatives against invasive alien species", Weed Technology, 19(3): 523-527. 7.2, 7.2

Coates, P. (2007), American Perceptions of Immigrant and Invasive Species: Strangers on the Land, Berkeley, CA (University of California Press). 5.5

Colautti, R.I., McIsaac, H.J. (2004), "A neutral terminology to define 'invasive' species", Diversity and Distributions, 10(2): 135-141, doi:10.1111/j.1366-9516.2004.00061.x. 3.1, 5.2, 7.2

Cook, D., Proctor, W. (2007), "Assessing the threat of exotic plant pests", Ecological Economics, 63(2-3): 594-604, doi:10.1016/j.ecolecon.2006.12.021. 7.2

Crall, A.W., Meyerson, L.A., Stohlgren, T.J., Jarnevich, C.S., Newman, G.J., Graham, J. (2006), "Show me the numbers: what data currently exist for non-native species in the USA?", Frontiers in Ecology and the Environment, 4(8): 414-418, doi:10.1890/15409295(2006)4[414:SMTNWD]2.0.CO;2. 4.1

Daehler, C.C. (1998), "The taxonomic distribution of invasive angiosperm plants: ecological insights and comparison to agricultural weeds", Biological Conservation, 84(2): 167-180, doi: 10.1016/S0006-3207(97)00096-7. 4.1

Daehler, C.C. (2001), "Two ways to be an invader, but one is more suitable for ecology", Bulletin of the Ecological Society of America, 82(1): 101-102. 3.1

Daehler, C.C. (2003), "Performance comparisons of co-occurring native and alien invasive plants: implications for conservation and restoration", Annual Review of Ecology and Systematics, 34: 183-211, doi:10.1146/annurev.ecolsys.34.011802.132403. 4.1

Daehler, C.C. (2007), "Invasive plant problems in the Hawaiian Islands and beyond: Insights from history and psychology", in Plant Invasions: Human perception, ecological impacts and management, (Eds.) Tokarska-Guzik, B., Brock, J., Brundu, G., Child, L., Daehler, C.C., Pyšek, P., pp. 3-20, Leiden, The Netherlands (Backhuys Publishers). 4.6 
Daehler, C.C., Denslow, J.S., Ansari, S., Kuo, H-C. (2004), "A risk-assessment system for screening out invasive pest plants from Hawaii and other Pacific Islands", Conservation Biology, 18(2): 360-368. 5.3

D'Antonio, C.M., Meyerson, L.A. (2002), "Exotic plant species as problems and solutions in ecological restoration: a synthesis", Restoration Ecology, 10(4): 703-713. 5.1, 6.3

Davis, M.A. (2006), "Invasion Biology 1958-2005: The Pursuit of Science and Conservation", in Conceptual ecology and invasion biology: reciprocal approaches to nature, (Eds.) Cadotte, M.W., McMahon, S.M., Fukami, T., pp. 35-64, Berlin (Springer). 3.2, 7.1

Davis, M.A., Thompson, K. (2000), "Eight Ways to be a Colonizer; Two Ways to be an Invader: A Proposed Nomenclature Scheme for Invasion Ecology", Bulletin of the Ecological Society of America, 81: 226-230. Related online version (cited on 9 July 2008):

http://www.macalester.edu/ davis/8ways.pdf. 3.1

Davis, M.A., Grime, J.P., Thompson, K. (2000), "Fluctuating resources in plant communities: a general theory of invasibility", Journal of Ecology, 88(3): 528-534. 4.1

Davis, M.A., Thompson, K., Grime, J.P. (2001), "Charles S. Elton and the dissociation of invasion ecology from the rest of ecology", Diversity and Distributions, 7: 97-102. Related online version (cited on 9 July 2008):

http://www.macalester.edu/ davis/DDI.pdf. 7.1

Dehnen-Schmutz, K., Touza, J., Perrings, C., Williamson, M. (2007a), "A century of the ornamental plant trade and its impact on invasion success", Diversity and Distributions, 13(5): 527-534, doi:10.1111/j.1472-4642.2007.00359.x. 4.6

Dehnen-Schmutz, K., Touza, J., Perrings, C., Williamson, M. (2007b), "The horticultural trade and ornamental plant invasions in Britain", Conservation Biology, 21(1): 224-231. 4.6

Deutschewitz, K., Lausch, A., Kuhn, I., Klotz, S. (2003), "Native and alien plant species richness in relation to spatial heterogeneity on a regional scale in Germany", Global Ecology and Biogeography, 12(4): 299-311. 4.7

Diamond, J.M. (1983), "Laboratory, field and natural experiments", Nature, 304: 586-587, doi: 10.1038/304586a0. 4.3

Didham, R.K., Tylianakis, J.M., Hutchison, M.A., Ewers, R.M., Gemmell, N.J. (2005), "Are invasive species the drivers of ecological change?", Trends in Ecology E Evolution, 20(9): 470474. 7.1

Didham, R.K., Tylianakis, J.M., Gemmell, N.J., Rand, T.A., Ewers, R.M. (2007), "Interactive effects of habitat modification and species invasion on native species decline", Trends in Ecology \& Evolution, 22(9): 489-496. 4.4

Dietz, H., Edwards, P.J. (2006), "Recognition that causal processes change during plant invasion helps explain conflicts in evidence", Ecology, 87(6): 1359-1367, doi:10.1890/00129658(2006)87[1359:RTCPCD]2.0.CO;2. 4.2

Dietz, H., Kueffer, C., Parks, C.G. (2006), "MIREN: A New Research Network Concerned with Plant Invasion into Mountain Areas", Mountain Research and Development, 26(1): 80-81. 7.2

Domènech, R., Vilà, M., Pino, J., Gesti, J. (2005), "Historical land-use legacy and Cortaderia selloana invasion in the Mediterranean region", Global Change Biology, 11(7): 1054-1064, doi: 10.1111/j.1365-2486.2005.00965.x. 4.7

Living Reviews in Landscape Research

http://www. livingreviews.org/lrlr-2008-2 
Donald, P.F., Evans, A.D. (2006), "Habitat connectivity and matrix restoration: the wider implications of agri-environment schemes", Journal of Applied Ecology, 43(2): 209-218, doi: 10.1111/j.1365-2664.2006.01146.x. 4.7

Drake, D., Hunt, T. (Eds.) (2007), Rats, humans, and their impacts on islands: integrating historical and contemporary ecology, Proceedings of an interdisciplinary conference, University of Hawaii, 27-31 March 2007, Honolulu, USA (University of Hawaii at Manoa). 7.1

Drake, J.A., Mooney, H.A., di Castri, F., Groves, R.H., Kruger, F.J., Rejmanek, M., Williamson, M. (Eds.) (1989), Biological Invasions: A Global Perspective, vol. 37 of SCOPE, Chichester; New York (Wiley). 4.1, 5.1, 7.1, 7.2

Drake, J.M., Keller, R.P. (2004), "Environmental justice alert: do developing nations bear the burden of risk for invasive species?", BioScience, 54(8): 718-719. 5.5

Elton, C.S. (1958), The Ecology of Invasions by Animals and Plants, London (Methuen). 4.3, 7.1

Elzinga, A. (2008), "Participation", in Handbook of Transdisciplinary Research, (Eds.) Hirsch Hadorn, G., Hoffmann-Riem, H., Biber-Klemm, S., Grossenbacher-Mansuy, W., Joye, D., Pohl, C., Wiesmann, U., Zemp, E., pp. 345-360, Heidelberg (Springer). 2, 8

Eppstein, M.J., Molofsky, J. (2007), "Invasiveness in plant communities with feedbacks", Ecology Letters, 10(4): 253-263, doi:10.1111/j.1461-0248.2007.01017.x. 4.4

Facon, B., Genton, B.J., Shykoff, J., Jarne, P., Estoup, A., David, P. (2006), "A general ecoevolutionary framework for understanding bioinvasions", Trends in Ecology 8 Evolution, 21(3): 130-135, doi:10.1016/j.tree.2005.10.012. 4.2, 4.3

Finnoff, D., Shogren, J.F., Leung, B., Lodge, D. (2007), "Take a risk: Preferring prevention over control of biological invaders", Ecological Economics, 62(2): 216-222, doi: doi:10.1016/j.ecolecon.2006.03.025. 6.3

Folke, C., Hahn, T., Olsson, P., Norberg, J. (2005), "Adaptive governance of socialecological systems", Annual Review of Environment and Resources, 30: 441-473, doi: 10.1146/annurev.energy.30.050504.144511. 7.1

Foster, J., Sandberg, L.A. (2004), "Friends or foe? Invasive species and public green space in Toronto", Geographical Review, 94(2): 178-198. 5.5

Franks, S.J., Pratt, P.D., Dray, F.A., Simms, E.L. (2004), "Selection for Resistance in Invasive Plants", Weed Technology, 18(5): 1486-1489, doi:10.1614/0890037X(2004)018[1486:SFRIIP]2.0.CO;2. 4.7

Fridley, J.D., Stachowicz, J.J., Naeem, S., Sax, D.F., Seabloom, E.W., Smith, M.D., Stohlgren, T.J., Tilman, D., Von Holle, B. (2007), "The invasion paradox: Reconciling pattern and process in species invasions", Ecology, 88(1): 3-17, doi:10.1890/0012-9658(2007)88[3:TIPRPA]2.0.CO;2. 4.3

Funtowicz, S.O., Ravetz, J.R. (1993), "Science for the post-normal age", Futures, 25(7): 739-755, doi:10.1016/0016-3287(93)90022-L. 1, 2, 2

Galison, P. (1999), "Trading Zone: Coordinating Action and Belief", in The Science Studies Reader, (Ed.) Biagioli, M., pp. 137-60, New York; London (Routledge). 7.2 
Genovesi, P. (2007), "Limits and Potentialities of Eradication as a Tool for Addressing Biological Invasions", in Biological Invasions, (Ed.) Nentwig, W., pp. 385-402, Berlin (Springer). 6.2, 6.3, 6.3

Gobster, P.H., Hull, R.B. (Eds.) (2000), Restoring Nature: Perspectives from the Social Sciences and Humanities, Washington, DC (Island Press). Related online version (cited on 11 July 2008): http://books.google.com/books?id=7unEgjxHhd8C. 7.1

Grotkopp, E., Rejmánek, M., Rost, T.L. (2002), "Toward a Causal Explanation of Plant Invasiveness: Seedling Growth and Life-History Strategies of 29 Pine (Pinus) Species", American Naturalist, 159(4): 396-419, doi:10.1086/338995. 4.1

Gurevitch, J., Padilla, D.K. (2004), "Are invasive species a major cause of extinctions?", Trends in Ecology \&6 Evolution, 19(9): 470-474. 5.1

Gutierrez, A.P., Regev, U. (2005), "The bioeconomics of tritrophic systems: applications to invasive species", Ecological Economics, 52(3): 383-396. 6.3

Hall, M. (2003), "Editorial: The native, naturalized and exotic - plants and animals in human history", Landscape Research, 28(1): 5-9. 5.5

Hallman, G. (2007), "Phytosanitary Measures to Prevent the Introduction of Invasive Species", in Biological Invasions, (Ed.) Nentwig, W., pp. 367-384, Berlin (Springer). 6.1

Hastings, A., Cuddington, A., Davies, K.F., Dugaw, C.J., Elmendorf, S., Freestone, A., Harrison, S., Holland, M., Lambrinos, J., Malvadkar, U., Melbourne, B.A., Moore, K., Taylor, C., Thomson, D. (2005), "The spatial spread of invasions: new developments in theory and evidence", Ecology Letters, 8: 91-101, doi:10.1111/j.1461-0248.2004.00687.x. Related online version (cited on 9 July 2008):

http://oak. cats. ohiou.edu/ cuddingt/pubs/hastings2005.pdf. 4.5

Hastings, A., Halla, R.J., Taylor, C.M. (2006), "A simple approach to optimal control of invasive species", Theoretical Population Biology, 70(4): 431-435, doi:10.1016/j.tpb.2006.05.003. 7.2

Hegamyer, K., Nash, S.P., Smallwood, P.D. (2003), "The early detectives: how to use volunteers against invasive species. Case studies of volunteer early detection programs in the U.S.", Richmond, Virginia, USA (The University of Richmond, Environmental Studies Program). 6.2

Hellström, T., Jacob, M. (2003), "Boundary organisations in science: from discourse to construction", Science and Public Policy, 30(4): 235-238. 2, 7.2, 7.2

Hiebert, R.D. (1996), "Prioritizing Invasive Plants and Planning for Management", in Assessment and Management of Plant Invasions, (Eds.) Luken, J.O., Thieret, J.W., pp. 195-212, New York, Berlin, Hong Kong, London, Tokyo (Springer). 6.3

Higgins, S.I., Azorin, E.J., Cowling, R.M., Morris, M.J. (1997), “A dynamic ecological-economic model as a tool for conflict resolution in an invasive-alien-plant, biological control and nativeplant scenario", Ecological Economics, 22(2): 141-154. 7.2

Higgs, E. (2003), Nature by Design: People, Natural Process, and Ecological Restoration, Cambridge, MA (MIT Press). Related online version (cited on 11 July 2008):

http://books.google.com/books?id=SHEI1cTt9k0C. 7.1

Hirsch, G. (1993), "Wieso ist ökologisches Handeln mehr als eine Anwendung ökologischen Wissens? Überlegungen zur Umsetzung ökologischen Wissens in ökologisches Handeln", GAIA, 2(3): 141151. 2

Living Reviews in Landscape Research

http://www. livingreviews.org/lrlr-2008-2 
Hirsch, G. (1995), "Beziehungen zwischen Umweltforschung und disziplinärer Forschung", GAIA, 4(5-6): 302-314. 2

Hirsch Hadorn, G. (Ed.) (2003), Unity of Knowledge in Transdisciplinary Research for Sustainability, Oxford (EOLSS Publishers). 1, 2

Hirsch Hadorn, G., Maier, S., Wölfing Kast, S. (2002), "Restrictions \& options: a heuristic tool to integrate knowledge for strategies towards a sustainable development", International Journal of Sustainable Development and World Ecology, 9(3): 193-207. 7.1

Hirsch Hadorn, G., Hoffmann-Riem, H., Biber-Klemm, S., Grossenbacher-Mansuy, W., Joye, D., Pohl, C., Wiesmann, U., Zemp, E. (Eds.) (2008), Handbook of Transdisciplinary Research, Heidelberg (Springer). 2

Hobbs, R.J. (2000), "Land-use changes and invasions", in Invasive Species in a Changing World, (Eds.) Mooney, H.A., Hobbs, R.J., pp. 55-64, Washington, DC (Island Press). Related online version (cited on 11 July 2008):

http://books.google.com/books?id=hCoJiTo7I3wC. 4.7

Hobbs, R.J., Arico, S., Aronson, J., Baron, J.S., Bridgewater, P.B., Cramer, V.A., Epstein, P.R., Ewel, J.J., Klink, C.A., Lugo, A.E., Norton, D., Ojima, D., Richardson, D.M., Sanderson, E.W., Valladares, F., Vila, M., Zamora, N., Zobel, M. (2006), "Novel ecosystems: theoretical and management aspects of the new ecological world order", Global Ecology and Biogeography, 15 (1): 1-7, doi:10.1111/j.1466-822X.2006.00212.x. 5.1

Holt, R.D., Barfield, M., Gomulkiewicz, R. (2005), "Theories of Niche Conservatism and Evolution: Could Exotic Species be Potential Tests?", in Species Invasions. Insights into Ecology, Evolution, and Biogeography, (Eds.) Sax, D.F., Stachowicz, J.J., Gaines, S.D., pp. 259-290, Sunderland, MA (Sinauer). 4.3

Horan, R.D., Lupi, F. (2005), "Tradeable risk permits to prevent future introductions of invasive alien species into the Great Lakes", Ecological Economics, 52(3): 289-304. 6.1

Hulme, P.E. (2006), "Beyond control: wider implications for the management of biological invasions", Journal of Applied Ecology, 43(5): 835-847, doi:10.1111/j.1365-2664.2006.01227.x. 6.1, $6.2,6.3$

Jay, M., Morad, M. (2006), "The socioeconomic dimensions of biosecurity: the New Zealand experience", International Journal of Environmental Studies, 63(3): 293-302. 7.1

Keane, R.M., Crawley, M.J. (2002), "Exotic plant invasions and the enemy release hypothesis", Trends in Ecology \& Evolution, 17(4): 164-170. 4.3

Kendle, A.D., Rose, J.E. (2000), "The aliens have landed! What are the justifications for "native only' policies in landscape plantings?", Landscape and Urban Planning, 47(1): 19-31, doi: 10.1016/S0169-2046(99)00070-5. 5.2

Klein, J.T., Grossenbacher-Mansuy, W., Häberli, R., Bill, A., Scholz, R.W., Welti, M. (Eds.) (2001), Transdisciplinarity: Joint Problem Solving among Science, Technology, and Society. An Effective Way for Managing Complexity, Basel, Boston, Berlin (Birkhäuser). Related online version (cited on 11 July 2008):

http://books.google.com/books?id=izLohzG9YDEC. 1

Knowler, D., Barbier, E. (2005), "Importing exotic plants and the risk of invasion: are marketbased instruments adequate?", Ecological Economics, 52(3): 341-354. 6.1 
Kolar, C.S., Lodge, D.M. (2002), "Ecological predictions and risk assessment for alien fishes in North America", Science, 298(5596): 1233-1236. 4.2

Kolar, C.S., Lodge, T.S. (2001), "Progress in invasion biology: predicting invaders", Trends in Ecology \& Evolution, 16(4): 199-204. 4.1, 4.2

Kowarik, I. (2003), "Human agency in biological invasions: secondary releases foster naturalisation and population expansion of alien plant species", Biological Invasions, 5(4): 293-312, doi:10.1023/B:BINV.0000005574.15074.66. 3.2, 4.7, 6.1, 7.1, 8

Kowarik, I., von der Lippe, M. (2007), "Pathways in Plant Invasions", in Biological Invasions, (Ed.) Nentwig, W., pp. 29-47, Berlin (Springer). 4.6

Kueffer, C. (2006), "Integrative ecological research: Case-specific validation of ecological knowledge for environmental problem solving", GAIA, 15(2): 115-120. 4.4, 8

Kueffer, C., Daehler, C. (2008), "A habitat-classification framework and typology for understanding, valuing and managing invasive species impacts", in Management of Invasive Weeds, (Ed.) Inderjit, p. accepted, Berlin (Springer). 4.7, 5.1

Kueffer, C., Hirsch Hadorn, G., Bammer, G., van Kerkhoff, L., Pohl, C. (2007a), "Towards a publication culture in transdisciplinary research", GAIA, 16(1): 22-26. 2

Kueffer, C., Schumacher, E., Fleischmann, K., Edwards, P.J., Dietz, H. (2007b), "Strong belowground competition shapes tree regeneration in invasive Cinnamomum verum forests", Journal of Ecology, 95(2): 273-282, doi:10.1111/j.1365-2745.2007.01213.x. 5.1

Kühn, I., Klotz, S. (2007), "From Ecosystem Invasibility to Local, Regional and Global Patterns of Invasive Species", in Biological Invasions, (Ed.) Nentwig, W., pp. 181-196, Berlin (Springer). 4.5

Kwa, C. (2005), "Local ecologies and global science: discourses and strategies of the International Geosphere-Biosphere Programme", Social Studies of Science, 35(6): 923-950. 7.2

La Sorte, F.A., McKinney, M.L., Pyšek, P. (2007), "Compositional similarity among urban floras within and across continents: biogeographical consequences of human-mediated biotic interchange", Global Change Biology, 13(4): 913-921. 4.7

Larson, B.M.H. (2005), "The war of the roses: demilitarizing invasion biology", Frontiers in Ecology and the Environment, 3(9): 495-500. 5.2

Levine, J.M., Vilà, M., D’Antonio, C.M., Dukes, J.S., Grigulis, K., Lavorel, S. (2003), "Mechanisms underlying the impacts of exotic plant invasions", Proceedings of the Royal Society of London, Series B: Biological Sciences, 270(1517): 775-781, doi:10.1098/rspb.2003.2327. 4.1, 5.1

Levine, J.M., Adler, P.B., Yelenik, S.G. (2004), "A meta-analysis of biotic resistance to exotic plant invasions", Ecology Letters, 7(10): 975-989, doi:10.1111/j.1461-0248.2004.00657.x. 4.3

Lockwood, J.L., Cassey, P., Blackburn, T.M. (2005), "The role of propagule pressure in explaining species invasions", Trends in Ecology EF Evolution, 20(5): 223-228. 4.1

Lodge, D.M., Shrader-Frechette, K. (2003), "Nonindigenous Species: Ecological Explanation, Environmental Ethics, and Public Policy", Conservation Biology, 17(1): 31-37, doi:10.1046/j.15231739.2003.02366.x. 5.2 
Lodge, D.M., Williams, S., MacIsaac, H.J., Hayes, K.R., Leung, B., Reichard, S., Mack, R.N., Moyle, P.B., Smith, M., Andow, D.A., Carlton, J.T., McMichael, A. (2006), "Biological invasions: Recommendations for U.S. policy and management", Ecological Applications, 16(6): 2035-2054. 3.1, 4.6, 5.3, 6, 6.1, 6.2, 6.3, 6.3, 7.1, 7.2

Lonsdale, W.M. (1999), "Global patterns of plant invasions and the concept of invasibility", Ecology, 80(5): 1522-1536. 4.1

Mack, R., Barrett, S.C.H. (2002), "Predicting Invasions of Nonindigenous Plants and Plant Pests", Washington, DC (National Academy Press). Related online version (cited on 15 July 2008): http://www.nap.edu/catalog.php?record_id=10259. 4.1, 4.2, 4.6, 5.3, 6.3

Mack, R.N. (2001), "Motivations and consequences of the human dispersal of plants", in The Great Reshuffling: Human Dimensions of Invasive Alien Species, (Ed.) McNeely, J.A., pp. 2334, Gland, Switzerland and Cambridge, UK (IUCN). 4.6

Mack, R.N., Lonsdale, W.M. (2002), "Eradicating invasive plants: Hard-won lessons for islands", in Turning the tide: the eradication of invasive species, (Eds.) Veitch, C.R., Clout, M.N., Proceedings of the international conference on eradication of invasive species, held at the University of Auckland, 19 - 23 February 2001, pp. 164-172, Gland, Switzerland and Cambridge, UK (IUCN Publications). Related online version (cited on 11 July 2008):

http: //books.google.com/books?id=CI8531CO-dsC. 6.3

Mack, R.N., Simberloff, D., Lonsdale, W.M., Evans, H.C., Clout, M.N., Bazzaz, F.A. (2000), "Biotic invasions: causes, epidemiology, global consequences and control", Ecological Applications, 10(3): $689-710.1,3.1,5.1,7.2$

Macpherson, A.J., Moore, R., Provencher, B. (2006), "A dynamic principal-agent model of humanmediated aquatic species invasions", Agricultural and Resource Economics Review, 35(1): 144154. 7.2

Marchetti, M.P., Moyle, P B, Levine, R. (2004), "Invasive species profiling: exploring characteristics of non-native fishes across invasion stages in California", Freshwater Biology, 49: 646-661. 4.2

Maskell, L.C., Firbank, L.G., Thompson, K., Bullock, J.M., Smart, S.M. (2006), "Interactions between non-native plant species and the floristic composition of common habitats", Journal of Ecology, 94(6): 1052-1060, doi:10.1111/j.1365-2745.2006.01172.x. 4.7

McDowall, R.M. (1994), Gamekeepers for the Nation: The Story of New Zealand's Acclimatisation Societies 1861-1990, Christchurch, New Zealand (Canterbury University Press). 7.1

McNeely, J.A. (Ed.) (2001), The Great Reshuffling: Human Dimensions of Invasive Alien Species, Gland, Switzerland and Cambridge, UK (IUCN). Related online version (cited on 11 July 2008): http://books.google.de/books?id=sE6jEHVvwYAC. 3.1, 4.6

McNeely, J.A., Mooney, H.A., Neville, L.E., Schei, P., Waage, J.K. (Eds.) (2001), A Global Strategy on Invasive Alien Species, Gland, Switzerland and Cambridge, UK (IUCN). Related online version (cited on 11 July 2008):

http://www.gisp.org/publications/brochures/globalstrategy.pdf. 1

Mehta, S.V., Haight, R.G., Homans, F.R., Polasky, S., Venette, R.C. (2007), "Optimal detection and control strategies for invasive species management", Ecological Economics, 61(2/3): 237245. 6.2 
Melbourne, B.A., Cornell, H.V., Davies, K.F., Dugaw, C.J., Elmendorf, S., Freestone, A.L., Hall, R.J., Harrison, S., Hastings, A., Holland, M., Holyoak, M., Lambrinos, J., Moore, K., Yokomizo, H. (2007), "Invasion in a heterogeneous world: resistance, coexistence or hostile takeover?", Ecology Letters, 10(1): 77-94. 4.5

Messing, R.H., Wright, M.G. (2006), "Biological control of invasive species: solution or pollution?", Frontiers in Ecology and the Environment, 4(3): 132-140. 6.3

Meyerson, L.A., Mooney, H.A. (2007), "Invasive alien species in an era of globalization", Frontiers in Ecology and the Environment, 5(4): 199-208. 4.6, 7.2, 7.2

Millennium Ecosystem Assessment (2005), "Ecosystems and Human Well-being: Biodiversity Synthesis", Washington, DC (World Resources Institute). Related online version (cited on 24 June 2008):

http://www.millenniumassessment .org/documents/document. 354.aspx.pdf. 1, 3.1, 5.1, 7.2

Minton, M.S., Verling, E., Miller, A.W., Ruiz, G.M. (2005), "Reducing propagule supply and coastal invasions via ships: effects of emerging strategies", Frontiers in Ecology and the Environment, 3(6): 304-308, doi:10.1890/1540-9295(2005)003[0304:RPSACI]2.0.CO;2. 6.1

Mooney, H.A., Hobbs, R.J. (Eds.) (2000), Invasive Species in a Changing World, Washington, DC (Island Press). Related online version (cited on 11 July 2008):

http://books.google.com/books?id=hCoJiTo7I3wC. 4.4

Mooney, H.A., Mack, R.N., McNeely, J.A., Neville, L.E., Schei, P.J., Waage, J.K. (Eds.) (2005), Invasive Alien Species: A New Synthesis, vol. 63 of SCOPE, Washington, London (Island Press). $1,3.1,3.2,4.6,7.2$

Myers, J.H., Bazely, D.R. (2003), Ecology and Control of Introduced Plants, Cambridge (Cambridge University Press). Related online version (cited on 9 July 2008):

http://books.google.com/books?id=g2yI1g2ZgX4C. 6.3

Myers, J.H., Simberloff, D., Kuris, A.M., Carey, J.R. (2000), "Eradication revisited: dealing with exotic species", Trends in Ecology \& Evolution, 15(8): 316-320, doi:10.1016/S01695347(00)01914-5. 6.2, 6.3, 6.3, 6.3

Nentwig, W. (Ed.) (2007), Biological Invasions, vol. 193 of Ecological Studies, Berlin (Springer). 7.2

Nowotny, H., Scott, P., Gibbons, M. (2001), Re-Thinking Science: Knowledge and the Public in an Age of Uncertainty, Cambridge, UK (Polity Press). 1, 2

Olson, L.J. (2007), "The economics of terrestrial invasive species: a review of the literature", Agricultural and Resource Economics Review, 35(1): 178-194. 5.4, 6.3, 7.2

Orians, G.H., Buckley, J., Clark, W., Gilpin, M., Jordan, C., Lehman, J., May, R., Robilliard, G., Simberloff, D., Erckmann, W., Policansky, D., Grossblatt, N. (1986), "Ecological Knowledge and Environmental Problem Solving: Concepts and Case Studies", Washington, DC (National Academy Press). Related online version (cited on 11 July 2008):

http://www.nap.edu/catalog.php?record_id=645. 4.4

Parker, I.M., Simberloff, D., Lonsdale, W.M., Goodell, K., Wonham, M., Kareiva, P.M., Williamson, M.H., Von Holle, B., Moyle, P.B., Byers, J.E., Goldwasser, L. (1999), "Impact: Towards a framework for understanding the ecological effects of invaders", Biological Invasions, 1(1): 3-19. 5.1

Living Reviews in Landscape Research

http://www. livingreviews.org/lrlr-2008-2 
Pauchard, A., Alaback, P.B. (2004), "Influence of elevation, land use, and landscape context on patterns of alien plant invasions along roadsides in protected areas of South-Central Chile", Conservation Biology, 18(1): 238-248. 4.7

Pauchard, A., McKinney, M.L. (2006), "Biological Invasions across Scales: New Insights - Introduction", Biological Invasions, 8(3): 397-398, doi:10.1007/s10530-005-5785-6. 4.5

Perrings, C. (2005), "The Socioeconomic Links between Invasive Alien Species and Poverty", Nairobi, Kenya (Global Invasive Species Programme). 5.5

Perrings, C., Dehnen-Schmutz, K., Touza, J., Williamson, M. (2005), "How to manage biological invasions under globalization", Trends in Ecology \& Evolution, 20(5): 212-215. 6.1

Petersen, C., Huntley, B. (2005), "Mainstreaming Biodiversity in Production Landscapes", Washington, DC (Global Environment Facility). 4.7

Peterson, A.T. (2003), "Predicting the geography of species' invasions via ecological niche modeling", Quarterly Review of Biology, 78(4): 419-433. 4.5

Pheloung, P.C., Williams, P.A., Halloy, S.R. (1999), "A weed risk assessment model for use as a biosecurity tool evaluating plant introductions", Journal of Environmental Management, 57(4): 239-251, doi:10.1006/jema.1999.0297. 5.3

Pielke Jr, R.A. (2002), "Policy, politics and perspective", Nature, 416(6879): 367-368. 2

Pimentel, D., Zuniga, R., Morrison, D. (2005), "Update on the environmental and economic costs associated with alien-invasive species in the United States", Ecological Economics, 52(3): 273288, doi:10.1016/j.ecolecon.2004.10.002. 1, 3.1, 5.4

Plowes, R.M., Dunn, J.G., Gilbert, L.E. (2007), "The urban fire ant paradox: native fire ants persist in an urban refuge while invasive fire ants dominate natural habitats", Biological Invasions, 9 (7): 825-836, doi:10.1007/s10530-006-9084-7. 4.7

Pohl, C., Hirsch Hadorn, G. (2007), Principles for Designing Transdisciplinary Research, Munich, Germany (oekom). 1, 2, 2, 2, 7.2, 7.2, 8

ProClim (1997), "Research on Sustainability and Global Change - Visions in Science Policy by Swiss Researchers", Berne (ProClim). Related online version (cited on 24 June 2008): http://www.proclim.ch/Reports/Visions97/Visions_E.html. 2

Puth, L.M., Post, D.M. (2005), "Studying invasion: have we missed the boat?", Ecology Letters, $8(7): 715-721.4 .2$

Pyšek, P., Hulme, P.E. (2005), "Spatio-temporal dynamics of plant invasions: Linking pattern to process", Ecoscience, 12(3): 302-315, doi:10.1111/j.1461-0248.2005.00774.x. 4.5

Pyšek, P., Jaroš́́k, V., Chytrý, M., Kropáč, Z., Tichý, L., Wild, J. (2005), "Alien plants in temperate weed communities: prehistoric and recent invaders occupy different habitats", Ecology, $86(3): 772-785.4 .7$

Radosevich, S.R., Endress, B.A., Parks, C.G. (2005), "Defining a regional approach for invasive plant research and management", in Invasive Plants: Ecological and Agricultural Aspects, (Ed.) Inderjit, pp. 141-165, Basel (Birkhäuser). 6.1 
Reaser, J.K., Meyerson, L.A., Cronk, Q., De Poorter, M., Eldrege, L.G., Green, E., Kairo, M., Latasi, P., Mack, R.N., Mauremootoo, J., O’Dowd, D., Orapa, W., Sastroutomo, S., Saunders, A., Shine, C., Thrainsson, S., Vaiutu, L. (2007), "Ecological and socioeconomic impacts of invasive alien species in island ecosystems", Environmental Conservation, 34(2): 98-111. 5.1

Regan, T.J., McCarthy, M.A., Baxter, P.W. J, Panetta, F.D., Possingham, H.P. (2006), "Optimal eradication: when to stop looking for an invasive plant", Ecology Letters, 9(7): 759-766. 6.3

Reichard, S.H., White, P. (2001), "Horticulture as a pathway of invasive plant introductions in the United States", BioScience, 51(2): 103-113. 4.6, 6.1

Rejmanek, M. (1996), "A theory of seed plants invasiveness: the first sketch", Biological Conservation, 78(1): 171-181, doi:10.1016/0006-3207(96)00026-2. 4.1

Rew, L.J., Maxwell, B.D., Dougher, F.L., Aspinall, R. (2005), "Searching for a needle in a haystack: evaluating survey methods for non-indigenous plant species", Biological Invasions, 8(3): 523539. 6.2

Richardson, D.M. (1998), "Forestry trees as invasive aliens", Conservation Biology, 12(1): 18-26. 4.6

Richardson, D.M., Pyšek, P. (2006), "Plant invasions: merging the concepts of species invasiveness and community invasibility", Progress in Physical Geography, 30(3): 409-431. 4.1, 4.3

Richardson, D.M., Pys̆ek, P. (2008), "Fifty years of invasion ecology - the legacy of Charles Elton", Diversity and Distributions, 14(2): 161-168, doi:10.1111/j.1472-4642.2007.00464.x. 3.2

Richardson, D.M., Pys̆ek, P., Rejmánek, M., Barbour, M.G., Panetta, F.D., West, C.J. (2000), "Naturalization and invasion of alien plants: concepts and definitions", Diversity and Distributions, 6: 93-107, doi:10.1046/j.1472-4642.2000.00083.x. 3.1, 4.2

Robbins, P. (2004), "Comparing invasive networks: cultural and political biographies of invasive species", Geographical Review, 94(2): 139-156. 7.1

Roberts, P.D., Pullin, A.S. (2007), "The Effectiveness of Management Interventions Used to Control Ragwort Species", Environmental Management, 39(5): 691-706, doi:10.1007/s00267-0060039-7. 7.2

Rodriguez, L.F. (2006), "Can invasive species facilitate native species? Evidence of how, when, and why these impacts occur", Biological Invasions, 8(4): 927-939, doi:10.1007/s10530-005-5103-3. 5.1

Roux, D.J., Rogers, K.H., Biggs, H.C., Ashton, P.J., Sergeant, A. (2006), "Bridging the ScienceManagement Divide: Moving from Unidirectional Knowledge Transfer to Knowledge Interfacing and Sharing", Ecology and Society, 11(1): 4. URL (cited on 23 June 2008):

http://www.ecologyandsociety.org/vol11/iss1/art4/. 7.2

Ruiz, G.M., Carlton, J.T. (Eds.) (2003), Invasive Species: Vectors and Management Strategies, Washington, London (Island Press). Related online version (cited on 15 July 2008):

http://books.google.com/books?id=Oh_NfKDA8RQC. 4.6

Safford, R.J., Jones, C.G. (1998), "Strategies for land-bird conservation on Mauritius", Conservation Biology, 12(1): 169-176. 5.1

Sagoff, M. (2005), "Do non-native species threaten the natural environment?", Journal of Agricultural \& Environmental Ethics, 18(3): 215-236, doi:10.1007/s10806-005-1500-y. 5.2 
Sakai, A.K., Allendorf, F.W., Holt, J.S., Lodge, D.J., Molofsky, J., With, K.A., Baughman, S., Cabin, R.J., Cohen, J.E., Ellstrand, N.C., McCauley, D.E., O’Neil, P., Parker, I.M., Thompson, J.N., Weller, S.G. (2001), "The population biology of invasive species", Annual Review of Ecology and Systematics, 32: 305-332, doi:10.1146/annurev.ecolsys.32.081501.114037. 4.1

Sanders, N.J., Weltzin, J.F., Crutsinger, G.M., Fitzpatrick, M.C., Nuñez, M.A., Oswalt, C.M., Lane, K.E. (2007), "Insects mediate the effects of propagule supply and resource availability on a plant invasion", Ecology, 88(9): 2383-2391, doi:10.1890/06-1449.1. 4.4

Sax, D.F., Stachowicz, J.J., Brown, J.H., Bruno, J.F., Dawson, M.N., Gaines, S.D., Grosberg, R.K., Hastings, A., Holt, R.D., Mayfield, M.M., O'Connor, M.I., Rice, W.R. (2007), "Ecological and evolutionary insights from species invasions", Trends in Ecology 85 Evolution, 22(9): 465-471. 4.3

Schneider, L., Geoghegan, J. (2006), "Land abandonment in an agricultural frontier after a plant invasion: the case of Bracken Fern in Southern Yucatán, Mexico", Agricultural and Resource Economics Review, 35(1): 167-177. 4.7, 7.1

Shigesada, N., Kawasaki, K. (1997), Biological Invasions: Theory and Practice, Oxford, New York (Oxford University Press). Related online version (cited on 15 July 2008):

http://books.google.com/books?id=Ri-hle_zdpsC. 4.1, 4.5

Shrader-Frechette, K. (2001), "Non-Indigenous Species and Ecological Explanation", Biology \&6 Philosophy, 16(4): 507-519, doi:10.1023/A:1011953713083. 4.4, 5.2

Simberloff, D. (2003), "Confronting introduced species: a form of xenophobia?", Biological Invasions, 5(3): 179-192. 1, 5.2

Simberloff, D. (2005), "The politics of assessing risk for biological invasions: the USA as a case study", Trends in Ecology \&6 Evolution, 12(5): 216-222, doi:10.1016/j.tree.2005.02.008. 5.2, 5.3, 6.1

Simberloff, D. (2006), "Invasional meltdown 6 years later: important phenomenon, unfortunate metaphor, or both?", Ecology Letters, 9(8): 912-919, doi:10.1111/j.1461-0248.2006.00939.x. 4.1, 5.1

Simberloff, D., Parker, I.M., Windle, P.N. (2005), "Introduced species policy, management, and future research needs", Frontiers in Ecology and the Environment, 3(1): 12-20. 7.2

Smith, R.G., Maxwell, B.D., Menalled, F.D., Rew, L.J. (2006), "Lessons from agriculture may improve the management of invasive plants in wildland systems", Frontiers in Ecology and the Environment, 4(8): 428-434. 4.7, 6.3

Star, S.L., Griesemer, J.R. (1989), "Institutional Ecology, 'Translations' and Boundary Objects: Amateurs and Professionals in Berkeley's Museum of Vertebrate Zoology, 1907-39", Social Studies of Science, 19(3): 387-420. 7.2

Stohlgren, T.J., Binkley, D., Chong, G.W., A, Kalkhan. M, Schell, L.D., Bull, K.A., Otskul, Y., Newman, G., Bashkin, M., Son, Y. (1999), "Exotic plant species invade hot spots of native plant diversity", Ecological Monographs, 69(1): 25-46. 4.1

Strayer, D.L., Eviner, V.T., Jeschke, J.M., Pace, M.L. (2006), "Understanding the long-term effects of species invasions", Trends in Ecology \& Evolution, 21(11): 645-651. 5.1 
Tassin, J., Rivière, J-N, Cazanove, M., Bruzzese, E. (2006), "Ranking of invasive woody plant species for management on Réunion Island", Weed Research, 46(5): 388-403, doi:10.1111/j.13653180.2006.00522.x. 6.3

Theodoropoulos, D.I. (2003), Invasion Biology: Critique of a Pseudoscience, Blythe, CA (Avvar Books). 1, 5.2

Thomas, M.B., Reid, A.M. (2007), "Are exotic natural enemies an effective way of controlling invasive plants?", Trends in Ecology $\&$ Evolution, 22(9): 447-453, doi:10.1016/j.tree.2007.03.003. $6.3,6.3$

Thompson, K., Hodgson, J.G., Rich, T.C.G. (1995), "Native and alien invasive plants: more of the same?", Ecography, 18(4): 390-402. 4.1

Thompson, K., Austin, K.C., Smith, R.M., Warren, P.H., Angold, P.G., Gaston, K.J. (2003), "Urban domestic gardens (I): Putting small-scale plant diversity in context", Journal of Vegetation Science, 14(1): 71-78. 4.7

Thuiller, W., Richardson, D.M., Midgley, G.F. (2007), "Will Climate Change Promote Alien Plant Invasions?", in Biological Invasions, (Ed.) Nentwig, W., pp. 197-211, Berlin (Springer). 4.4

Trepl, L. (1990), "Research on the anthropogenic migration of plants and naturalization. Its history and current state of development", in Urban Ecology: Plants and Plant Communities in Urban Environments, (Eds.) Sukopp, H., Hejný, S, Kowarik, I., Papers presented at a symposium held during the 14th International Botanical Congress on 26-27th July 1987, The Hague, The Netherlands (SPB Academic Publishing). 3.2

Tu, M., Hurd, C., Randall, J.M. (2001), Weed Control Methods Handbook: Tools and Techniques for use in Natural Areas, Arlington, VA (The Nature Conservancy). URL (cited on 23 June 2008):

http://tncweeds.ucdavis.edu/handbook.html. 6.3

Vale, T.R., Parker, A.J. (1980), "Biogeography: research opportunities for geographers", Professional Geographer, 32(2): 149-157. 4.5

Veitch, C.R., Clout, M.N. (2001), "Human dimensions in the management of invasive species in New Zealand", in The Great Reshuffling: Human Dimensions of Invasive Alien Species, (Ed.) McNeely, J.A., pp. 63-74, Gland, Switzerland; Cambridge, UK (IUCN). 6.3

Vitousek, P.M. (1990), "Biological invasions and ecosystem processes: towards an integration of population biology and ecosystem studies", Oikos, 57(1): 7-13. 4.1, 5.1

Vitousek, P.M., Walker, L.R., Whiteaker, L.D., Mueller-Dombois, D., Matson, P.A. (1987), "Biological Invasion by Myrica faya Alters Ecosystem Development in Hawaii", Science, 238(4828): 802-804, doi:10.1126/science.238.4828.802. 5.1

Vitousek, P.M., Mooney, H.A., Lubchenco, J., Melillo, J.M. (1997), "Human Domination of Earth's Ecosystems", Science, 277(5325): 494-499, doi:10.1126/science.277.5325.494. 3.1

Von Holle, B., Motzkin, G. (2007), "Historical land use and environmental determinants of nonnative plant distribution in coastal southern New England", Biological Conservation, 136(1): 33-43, doi:10.1016/j.biocon.2006.10.044. 4.7

Warren, C.R. (2007), 'Perspectives on the 'alien' versus 'native' species debate: a critique of concepts, language and practice", Progress in Human Geography, 31(4): 427-446, doi: 10.1177/0309132507079499. 5.2

Living Reviews in Landscape Research

http://www. livingreviews . org/lrlr-2008-2 
Wilcox, B., Kueffer, C. (2008), "Transdisciplinarity in EcoHealth: Status and Future Prospects", EcoHealth, 5(1): 1-3, doi:10.1007/s10393-008-0161-5. 7.1

Williamson, M. (1996), Biological Invasions, vol. 15 of Population and Community Biology Series, London; New York (Chapman \& Hall). Related online version (cited on 11 July 2008): http://books.google.com/books?id=eWUdzI6j3V8C. 4.1, 4.2, 4.4, 4.5

Wilson, J.R.U., Procheş, S., Braschler, B., Dixon, E.S., Richardson, D.M. (2007), "The (bio)diversity of science reflects the interests of society", Frontiers in Ecology and the Environment, 5(8): 409-414, doi:10.1890/060077. 7.2

With, K.A. (2002), "The Landscape Ecology of Invasive Spread", Conservation Biology, 16(5): 1192-1203, doi:10.1046/j.1523-1739.2002.01064.x. Related online version (cited on 14 July 2008): http://www.k-state.edu/withlab/publications.html. 4.1, 4.5

Wittenberg, R., Cock, M.J.W. (Eds.) (2001), Invasive Alien Species: A Toolkit of Best Prevention and Management Practices, Wallingford, Oxon, UK (CAB International). Related online version (cited on 11 July 2008):

http://www.gisp.org/publications/toolkit/. 1, 5.2, 5.3, 6, 6.1, 6.2, 6.3, 6.3, 6.3

Zavaleta, E., Hobbs, R.J., Mooney, H.A. (2001), "Viewing invasive species removal in a wholeecosystem context", Trends in Ecology \& Evolution, 16(8): 454-459, doi:10.1016/S01695347(01)02194-2. 5.1, 6.3 